\title{
Site of Azido Substitution in the Sugar Moiety of Azidopyrimidine Nucleosides Influences the Reactivity of Aminyl Radicals Formed by Dissociative Electron Attachment
}

Mukesh Mudgal, ${ }^{\text {a }}$ Thao P. Dang, ${ }^{\text {a }}$ Adam J. Sobczak, ${ }^{\text {a }}$ Daniel A. Lumpuy, ${ }^{a}$ Priya Dutta, ${ }^{\mathrm{b}}$ Samuel Ward, ${ }^{\mathrm{b}}$ Katherine Ward, ${ }^{\mathrm{b}}$ Moaadh Alahmadi, ${ }^{\mathrm{b}}$ Anil Kumar, ${ }^{\mathrm{b}}$ Michael D. Sevilla, ${ }^{\mathrm{b}}$ Stanislaw F. Wnuk, ${ }^{\mathrm{a}, *}$ and Amitava Adhikary, ${ }^{\mathrm{b}, *}$

${ }^{a}$ Department of Chemistry and Biochemistry, Florida International University, Miami, Florida 33199, USA

${ }^{b}$ Department of Chemistry, Oakland University, Rochester, Michigan 48309, USA

Correspondingauthors:wnuk@fiu.edu,adhikary@oakland.edu

\section{SUPPORTING INFORMATION}

\section{CONTENTS}

1. Chemical Synthesis S2

1.1 Synthesis of deuterated sugar precursors (Schemes S1-S2) S3

1.2 Synthesis of deuterated pyrimidine nucleoside precursors $\quad$ S4

2. EPR Studies $\quad$ S7

2.1. Sample preparation and methods $\quad \mathrm{S} 7$

2.2 Additional EPR Spectra (Figures S1-S12) S9

2.3 Addition of aminyl radical to uracil base in 2 (Scheme S3) S22

3. Theoretical Studies $\quad$ S23

$\begin{array}{ll}\text { 4. References } & \text { S27 }\end{array}$ 


\section{Chemical Synthesis}

${ }^{1} \mathrm{H}(400 \mathrm{MHz})$ and ${ }^{13} \mathrm{C}(100 \mathrm{MHz})$ NMR spectra were determined with solutions in $\mathrm{CDCl}_{3}$ unless otherwise noted. Mass spectra (MS) were obtained with atmospheric pressure chemical ionization (APCI) technique and HRMS in AP-ESI mode. TLC was performed with Merck kieselgel $60-\mathrm{F}_{254}$ sheets with products detected with $254 \mathrm{~nm}$ light or by development of color with $\mathrm{I}_{2}$ or Ellman reagent. Merck kieselgel 60 (230-400 mesh) was used for column chromatography. HPLC purifications were performed using XTerra ${ }^{\circledR}$ preparative $\mathrm{RP}_{18}$ OBD ${ }^{\mathrm{TM}}$ column $(5 \mu \mathrm{m} 19 \times 150 \mathrm{~mm})$ with gradient program using $\mathrm{CH}_{3} \mathrm{CN} / \mathrm{H}_{2} \mathrm{O}$ as a mobile phase. Reagent grade chemicals were used, and solvents were dried by reflux over and distillation from $\mathrm{CaH}_{2}$ (except THF/potassium) under Ar.

\subsection{Synthesis of deuterated sugar precursors.}

The selectively deuterated 2-[ $\left.{ }^{2} \mathrm{H}\right]-\mathbf{1 0 a}, 3-\left[{ }^{2} \mathrm{H}\right]-\mathbf{1 0 b}$, and $4-\left[{ }^{2} \mathrm{H}\right]-\mathbf{1 1 c}$ ribofuranose precursors were prepared by modification of the literature protocols.

\subsubsection{Preparation of 2-[2 $\mathrm{H}]-1,2,3,5$-tetra- $O$-acetyl-D-ribofuranose 10a}

Diastereselective exchange of the $\mathrm{H}$ at $\mathrm{C} 2$ of 2,3- $O$-isopropylidineribose 14a to $\mathrm{D}$ upon equilibration in TEA/ $\mathrm{D}_{2} \mathrm{O} /$ dioxaneTHF at $90{ }^{\circ} \mathrm{C}$ for 6 days gave $14 \mathbf{b}\left(>98 \%{ }^{2} \mathrm{H}\right)^{1}$ which was converted to 2-[ $\left[{ }^{2} \mathrm{H}\right]-1,2,3,5$-tetra- $O$-acetyl-D-ribofuranose 10a (Scheme $\mathrm{S} 1$ ).

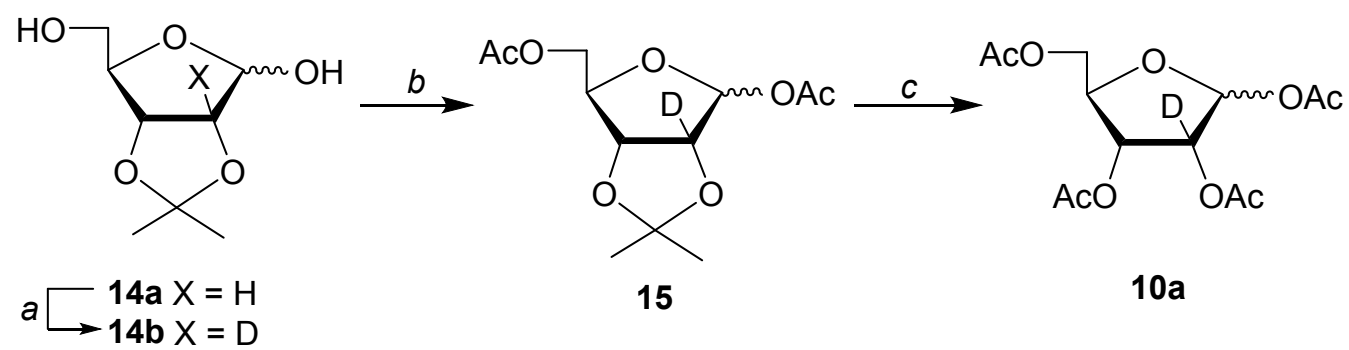

Reagents: (a) TEA/ $\mathrm{D}_{2} \mathrm{O} /$ dioxane/THF; (b) $\mathrm{Ac}_{2} \mathrm{O} /$ pyridine; (c) (i) $\mathrm{TFA} / \mathrm{H}_{2} \mathrm{O}$, (ii) $\mathrm{Ac}_{2} \mathrm{O} /$ pyridine

Scheme S1. Synthesis of 2-[2 $\mathrm{H}]-1,2,3,5$-tetra-O-acetyl-D-ribofuranose 10a.

2- $\left[{ }^{2} \mathrm{H}\right]-1,2,3,5-T e t r a-O$-acetyl-D-ribofuranose (10a). Solution of $\quad\left[2-{ }^{2} \mathrm{H}\right]-2,3-O-$ isopropylidene-D-ribofuranose $\mathbf{1 4 \mathbf { b } ^ { 1 }}(0.40 \mathrm{~g}, 2.1 \mathrm{mmol})$ in a mixture of $\mathrm{Ac}_{2} \mathrm{O} /$ pyridine $(1: 1,4.0$ $\mathrm{mL}$ ) was stirred at ambient temperature overnight. The concentrated residue was dissolved in EtOAc and washed with aqueous $\mathrm{HCl}, \mathrm{NaHCO}_{3}$, and $\mathrm{NaCl}$. Purification on silica gel column (EtOAc/hexane, 3:7) gave [2-2 $\mathrm{H}]-1,5-O$-diacetyl-2,3-O-isopropylidene-D-ribofuranose as an oily residue $(15,300 \mathrm{mg}, 52 \%)$. This material $(60 \mathrm{mg}, 0.23 \mathrm{mmol})$ was dissolved in $\mathrm{TFA} / \mathrm{H}_{2} \mathrm{O}(9: 1,2$ 
$\mathrm{mL}$ ) at $0{ }^{\circ} \mathrm{C}$ and stirred for $30 \mathrm{~min}$. The reaction mixture was concentrated, coevaporated with toluene, and dried to give [2-2 $\mathrm{H}]-1,5-O$-diacetyl-D-ribofuranose $(50 \mathrm{mg}, 98 \%)$ as an oily residue. Acetic anhydride $(0.5 \mathrm{~mL})$ and pyridine $(2 \mathrm{~mL})$ were added and stirring was continued overnight at ambient temperature. The reaction mixture was concentrated, dissolved in EtOAc, washed with aqueous $\mathrm{HCl}, \mathrm{NaHCO}_{3}$, and brine, and was dried over $\mathrm{MgSO}_{4}$. Purification on silica gel column (EtOAc/hexane, 3:7) gave only the $\beta$ anomer of $\mathbf{1 0 a}^{2}(56 \mathrm{mg}, 82 \%)$ as a clear oil: ${ }^{1} \mathrm{H}$ NMR was as for the commercial sample of 1,2,3,5-tetra- $O$-acetyl- $\beta$,D-ribofuranose ${ }^{3}\left[{ }^{1} \mathrm{H}\right.$ NMR $\delta$ 1.99 (s, 3, Ac), 2.00 (s, 3, Ac), 2.01 (s, 3, Ac), 2.04 (s, 4.2, Ac), 4.05 (dd, J=5.2, $11.9 \mathrm{~Hz}, 1$, H5'), 4.21-4.30 (m, 2, H5, H4), 5.24 (d, J=4.0 Hz, 1, H2), 5.25 ("q", J=4.8 Hz, 1, H3), 6.06 (s, 1, H1)] except for disappearance of $\mathrm{H} 2$ peak at $5.24 \mathrm{ppm}$ and simplification of proton splitting for $\mathrm{H} 3$ at $5.25 \mathrm{ppm}(\mathrm{d}, J=6.9 \mathrm{~Hz})$.

\subsubsection{Preparation of 3-[ $\left[{ }^{2} \mathrm{H}\right]-1,2,3,5$-tetra- $O$-acetyl-D-ribofuranose $\mathbf{1 0 b}$}

Compound 10b was prepared from diacetone-D-glucose with deuterium incorporation at C3 $(>98 \%)$ achieved by reduction of the 3-ketoglucose with $\mathrm{NaBD}_{4}$ to yield $3-\left[{ }^{2} \mathrm{H}\right]$-allofuranose ${ }^{3}$

16 Subsequent dehomologation of 16 with periodic acid $\left(\mathrm{H}_{5} \mathrm{IO}_{6} / \text { EtOAc }\right)^{4}$ followed by standard acetylation and acetolysis of 17a afforded 3-[ $\left[{ }^{2} \mathrm{H}\right]$ isotopomer $\mathbf{1 0 b}$ (Scheme S2).

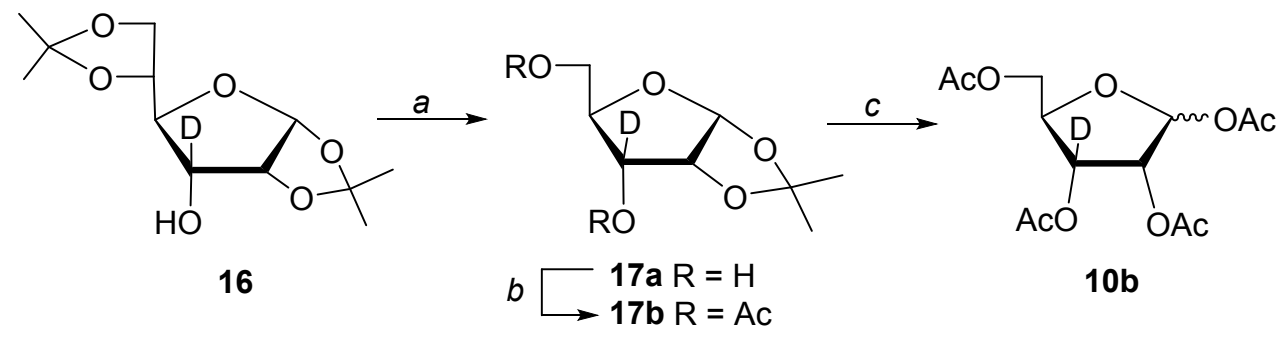

Reagents: (a) (i) $\mathrm{H}_{5} \mathrm{IO}_{6} / \mathrm{EtOAc}$, (ii) $\mathrm{NaBH}_{4} / \mathrm{EtOH}$; (b) $\mathrm{Ac}_{2} \mathrm{O} /$ pyridine; (c) (i) $\mathrm{TFA} / \mathrm{H}_{2} \mathrm{O}$, (ii) $\mathrm{Ac}_{2} \mathrm{O} /$ pyridine.

Scheme S2. Synthesis of 3-[ $\left.{ }^{2} \mathrm{H}\right]-1,2,3,5$-tetra- $O$-acetyl-D-ribofuranose 10b.

3-[$\left[{ }^{2} \mathbf{H}\right]-1,2-O$-Isopropylidene-D-ribofuranose (17a). A solution of 3-[ $\left.{ }^{2} \mathrm{H}\right]-1,2 ; 5,6-\mathrm{Di}-O$ isopropylidene- $\alpha, \mathrm{D}$-allose $\mathbf{1 6}^{3}(0.50 \mathrm{~g}, 1.9 \mathrm{mmol})$ in EtOAc $(12 \mathrm{~mL})$ and $\mathrm{H}_{5} \mathrm{IO}_{6}(0.57 \mathrm{~g}, 2.5$ mmol) was stirred at ambient for $3 \mathrm{~h}$. The precipitate formed was filtered off and washed with EtOAc. The combined filtrate was concentrated and was dissolved in EtOH (12 mL). $\mathrm{NaBH}_{4}$ was added (146 mg, $3.83 \mathrm{mmol}$ ) and stirring was continued for $12 \mathrm{~h}$. Neutralization with AcOH $(0.5 \mathrm{~mL})$ and evaporation of the volatiles gave an oily residue which was column 
chromatographed $\left(\mathrm{CHCl}_{3} / \mathrm{MeOH}, 9: 1\right)$ to yield $17 \mathbf{a}^{3}(280 \mathrm{mg}, 60 \%)$ with NMR data was as reported.

3-[$\left.{ }^{2} \mathbf{H}\right]-1,2,3,5-T e t r a-O$-acetyl-D-ribofuranose (10b). Acetylation of 17a $(0.28 \mathrm{~g}, 1.47$ mmol) with $\mathrm{Ac}_{2} \mathrm{O}$ /pyridine, as described for 10a, afforded 3-[ $\left.{ }^{2} \mathrm{H}\right]-3,5$-di- $O$-acetyl-1,2-O-

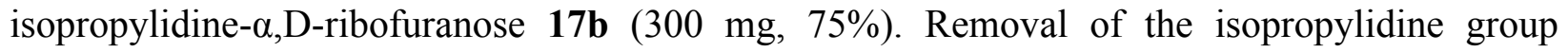
$\left(\mathrm{TFA} / \mathrm{H}_{2} \mathrm{O}\right)$ and acetylation $\left(\mathrm{Ac}_{2} \mathrm{O} /\right.$ pyridine $)$ of $\mathbf{1 7 b}(0.30 \mathrm{~g}, 1.10 \mathrm{mmol})$, as described for 10a, afforded $\mathbf{1 0 b}^{2-3}(\alpha / \beta, 1: 3 ; 310 \mathrm{mg}, 89 \%)$. ${ }^{1} \mathrm{H}$ NMR was as described above for 16 except for disappearance of $\mathrm{H} 3$ peaks at 5.25 and 5.16 ppm, simplification of $\mathrm{H}_{\beta}$ splitting within 4.21-4.30 ppm multiplet and the collapse of the quartet to triplet of $\mathrm{H} 4_{\alpha}$ peak at $4.35 \mathrm{ppm}(\mathrm{t}, J=3.7 \mathrm{~Hz})$, as well as simplification of proton splitting for $\mathrm{H} 2$ at 5.24 (s) and 5.14 (d, $J=4.6 \mathrm{~Hz}$ ).

\subsubsection{Preparation of 4-[2 $\mathrm{H}]-1,2,5-$ tri- $O$-acetyl-3-O-benzoyl-D-ribofuranose 11c}

The acyl protected 4-[2H]-ribofuranoside 11c was prepared from diacetone-D-glucose with deuterium incorporation at $>97 \%$ by $\mathrm{H} / \mathrm{D}$ exchange at $\mathrm{C} 4$ upon heating of diacetone 3ketoglucose in $\mathrm{D}_{2} \mathrm{O}$ /pyridine for 3 days followed by standard reduction, dehomologation and acetylation as reported. ${ }^{5}$

\subsection{Synthesis of deuterated pyrimidine nucleoside precursors}

Coupling ${ }^{6}$ of the acylated $2-\left[{ }^{2} \mathrm{H}\right]-\mathbf{1 0 a}, 3-\left[{ }^{2} \mathrm{H}\right]-\mathbf{1 0 b}$, and $4-\left[{ }^{2} \mathrm{H}\right]-\mathbf{1 1 c}$ ribofuranoses with persilylated uracil in the presence of trimethylsilyl trifluoromethanesulfonate (TMSOTf) followed by deacylation $\left(\mathrm{NH}_{3} / \mathrm{MeOH}\right)$ yielded selectively labeled uridines 12a-c in high yields ( $>97 \%$ of ${ }^{2} \mathrm{H}$, MS and ${ }^{1} \mathrm{H}$ NMR). Uridines $12 \mathbf{a}-\mathbf{c}$ as well as commercially available $\mathbf{8 a}$ and $\mathbf{8 b}$

and were converted to 2,2'-O-anhydrouridine derivatives $13 \mathbf{a}-\mathbf{c}, 9 \mathbf{a}$ and $9 \mathbf{b}$ employing Hampton and Nichol methodology ${ }^{7}$ (see Scheme 1 and 2).

Uridine (8a). Commercial sample of 8a had: ${ }^{1} \mathrm{H}$ NMR $\left(\mathrm{D}_{2} \mathrm{O}\right) \delta 3.70(\mathrm{dd}, J=12.8,4.4 \mathrm{~Hz}, 1$, H5"), 3.80 (dd, $J=12.8,3.0 \mathrm{~Hz}, 1, \mathrm{H}^{\prime}$ ), 4.03 ("q", $J=4.1 \mathrm{~Hz}, 1, \mathrm{H} 4$ '), 4.13 (t, $J=5.4$ Hz, 1, H3'), 4.25 (t, $\left.J=5.1 \mathrm{~Hz}, 1, \mathrm{H} 2^{\prime}\right), 5.89$ (d, $\left.J=8.1 \mathrm{~Hz}, 1, \mathrm{H} 5\right), 5.81$ (d, $\left.J=4.8 \mathrm{~Hz}, 1, \mathrm{H} 1^{\prime}\right), 7.77$ (d, $J=$ 8.1 Hz, 1, H6); MS (ESI) $m / z 245\left(\mathrm{MH}^{+}\right)$.

2'-[ $\left.{ }^{\mathbf{2}} \mathbf{H}\right]$-Uridine (12a). Procedure A. Step a. Uracil (32 $\mathrm{mg}, 0.28 \mathrm{mmol}$ ) and chlorotrimethylsilane $(0.047 \mathrm{~mL}, 0.040 \mathrm{~g}, 0.37 \mathrm{mmol})$ were dissolved in hexamethyldisilazane 
$(1.5 \mathrm{~mL})$ at $120{ }^{\circ} \mathrm{C}$ under $\mathrm{N}_{2}$, and stirred for $3 \mathrm{~h}$. The clear solution of the presilylated uracil was evaporated and immediately added to the solution of 2-[ $\left.{ }^{2} \mathrm{H}\right]-1,2,3,5$-tetra-O-acetyl-Dribofuranose (10a; $50 \mathrm{mg}, 0.16 \mathrm{mmol})$ in $\mathrm{MeCN}(4 \mathrm{~mL})$. Trimethylsilyl trifluoromethanesulfonate $(0.035 \mathrm{~mL}, 0.043 \mathrm{~g}, 0.20 \mathrm{mmol})$ was added and allowed to stir at ambient temperature for $15 \mathrm{~min}$. The reaction mixture was heated at $70{ }^{\circ} \mathrm{C}$ under $\mathrm{N}_{2}$ for $2 \mathrm{~h}$. Evaporation and standard work up $\left(\mathrm{EtOAc} / / \mathrm{NaHCO}_{3} / \mathrm{H}_{2} \mathrm{O}\right.$, brine) gave crude 2'-[ $\left.{ }^{2} \mathrm{H}\right]-2^{\prime}, 3^{\prime}, 5^{\prime}$-tri$O$-acetyluridine (52 mg, 90\%). Step $b$. $\mathrm{NH}_{3} / \mathrm{MeOH}(2 \mathrm{~mL})$ was added to the above material in $\mathrm{MeOH}(2 \mathrm{~mL})$ at $0{ }^{\circ} \mathrm{C}$. The reaction mixture was stirred for $6 \mathrm{~h}$, evaporated, washed with ether, and dried to give $\mathbf{1 2 a}^{1}(24.5 \mathrm{mg}, 85 \%)$ : ${ }^{1} \mathrm{H}$ NMR was as described above for $\mathbf{8 a}$ except for disappearance of $\mathrm{H} 2$ ' peak at $4.25 \mathrm{ppm}$ and simplification of proton splitting for $\mathrm{H} 1^{\prime}$ at $5.81 \mathrm{ppm}$ (s) and H3' at $4.13 \mathrm{ppm}(\mathrm{d}, J=4.6 \mathrm{~Hz})$. MS (ESI) $m / z 246\left(\mathrm{MH}^{+}\right)$.

$\mathbf{3}^{\prime}-\left[{ }^{\mathbf{2}} \mathbf{H}\right]$-Uridine (12b). Coupling of $\mathbf{1 0 b}(200 \mathrm{mg}, 0.63 \mathrm{mmol})$ with uracil by procedure A (step a) gave [3'-2 $\mathrm{H}]-2^{\prime}, 3^{\prime}, 5^{\prime}$-tri- $O$-acetyluridine (230 mg, 99\%). Subsequent deacetylation by procedure A (step $b$ ) gave $\mathbf{1 2 b}^{8}$ (140 mg, 97\%). ${ }^{1} \mathrm{H}$ NMR was as described for 8a except for disappearance of H3' peak at 4.13 ppm and simplification of proton splitting for $\mathrm{H} 2^{\prime}$ at $4.25 \mathrm{ppm}$ $(\mathrm{d}, J=4.6 \mathrm{~Hz})$ and $\mathrm{H}^{\prime}$ ' at $4.03 \mathrm{ppm}(\mathrm{t}, J=2.8 \mathrm{~Hz})$. MS (ESI) $m / z 246\left(\mathrm{MH}^{+}\right)$.

4'-[ $\left.^{2} \mathbf{H}\right]$-Uridine (12c). Coupling of 11c $(148 \mathrm{mg}, 0.39 \mathrm{mmol})$ with uracil by procedure A (step a) gave [4'-2 $\mathrm{H}]-2^{\prime}, 5^{\prime}-$ di- $O$-acetyl-3'-O-benzoyluridine $(110 \mathrm{mg}, 58 \%$ ). Subsequent deacetylation by procedure A (step $b$ ) gave $12 \mathrm{c}^{8}(55 \mathrm{mg}, 60 \%)$. ${ }^{1} \mathrm{H}$ NMR was as described for $8 \mathbf{a}$ except for disappearance of H4' peak at 4.03 ppm and simplification of proton splitting for H3' at $4.13 \mathrm{ppm}(\mathrm{d}, J=5.3 \mathrm{~Hz}), \mathrm{H} 5^{\prime}$ at $3.80 \mathrm{ppm}(\mathrm{d}, J=12.2 \mathrm{~Hz})$, and $\mathrm{H} 5 "$ at $3.70 \mathrm{ppm}(\mathrm{d}, J=12.2 \mathrm{~Hz})$. MS (ESI) $m / z 246\left(\mathrm{MH}^{+}\right)$.

1-(2,2'-Anhydro- $\beta$-D-arabinofuranosyl)uracil (9a). Procedure B. Uridine (8a, $50 \mathrm{mg}$, $0.21 \mathrm{mmol})$ was dissolved in DMF $(1.0 \mathrm{~mL})$ and was treated with diphenyl carbonate $(57 \mathrm{mg}$, $0.27 \mathrm{mmol})$ and $\mathrm{NaHCO}_{3}(5 \mathrm{mg})$. The reaction mixture was heated at $150{ }^{\circ} \mathrm{C}$ for $20 \mathrm{~min}$, cooled down and poured into cold ether $(5 \mathrm{~mL})$. Evaporation of the volatiles and purification of the residue on silica gel column $\left(\mathrm{CHCl}_{3} / \mathrm{MeOH}, 8: 2\right)$ afforded 9a ${ }^{7}(20 \mathrm{mg}, 43 \%):{ }^{1} \mathrm{H}$ NMR $\left(\mathrm{D}_{2} \mathrm{O}\right) \delta$ 3.47 (dd , $J=4.2,12.6 \mathrm{~Hz}, 1, \mathrm{H} 5$ '), 3.51 (dd , $J=3.6,12.6 \mathrm{~Hz}, 1, \mathrm{H} 5 "), 4.31$ ("dt", $J=1.8,3.8$ 
Hz, 1, H4'), 4.58 ("br s", 1, H3'), 5.38 (d, J=5.9 Hz, 1, H2'), 6.11 (d, J= 7.4 Hz, 1, H5), 6.45 (d, $\left.J=5.9 \mathrm{~Hz}, 1, \mathrm{H} 1^{\prime}\right), 7.83(\mathrm{~d}, J=7.4 \mathrm{~Hz}, 1, \mathrm{H} 6)$; MS (ESI) $m / z 227\left(\mathrm{MH}^{+}\right)$.

5,6- $\left[{ }^{2} \mathrm{H}_{2}\right]-1-\left(2,2^{\prime}\right.$-Anhydro- $\boldsymbol{\beta}$-D-arabinofuranosyl)uracil $(9 \mathrm{~b})$. Treatment of the commercially available 5,6-[$\left.{ }^{2} \mathrm{H}_{2}\right]$-uridine $8 \mathbf{b}(50 \mathrm{mg}, 0.20 \mathrm{mmol})$ by procedure B gave $\mathbf{9 b}(20 \mathrm{mg}$, $43 \%$ ) with identical physical, chemical, and spectroscopical properties as 9a except for the disappearance of H5 and H6 peaks at $6.11 \mathrm{ppm}$ and 7.83 ppm, respectively: MS (ESI) m/z 229 $\left(\mathrm{MH}^{+}\right)$.

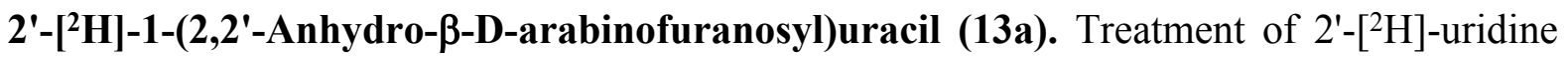
12a (35 mg, $0.14 \mathrm{mmol}$ ) by procedure B gave 13a $\mathbf{a}^{9}(22 \mathrm{mg}, 69 \%$ ) with identical spectroscopical properties as 9a except for the presence of residual $\mathrm{H} 2^{\prime}$ peak $(\sim<5 \%)$ and simplification of proton splitting for $\mathrm{H}^{\prime}$ at $6.45 \mathrm{ppm}(\mathrm{s})$ : MS (ESI) $m / z 228\left(\mathrm{MH}^{+}\right)$.

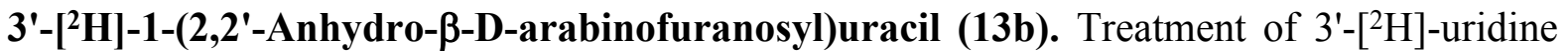
12b (50 mg, $0.20 \mathrm{mmol}$ ) by procedure B gave 13b (20 mg, 43\%) with identical spectroscopical properties as 9a except for the disappearance of $\mathrm{H}^{\prime}$ at $4.58 \mathrm{ppm}$ and simplification of proton splitting for H4' at $4.31 \mathrm{ppm}(" \mathrm{t} ", J=3.9 \mathrm{~Hz})$ : MS (ESI) $m / z 228\left(\mathrm{MH}^{+}\right)$.

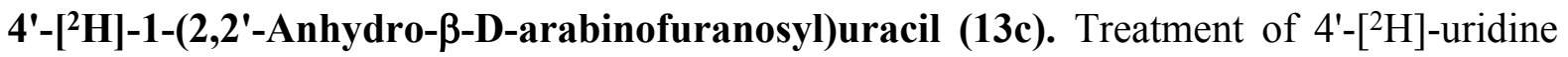
12c (44 mg, $0.18 \mathrm{mmol}$ ) by procedure B gave 13c (25 mg, 63\%) with identical spectroscopical properties as 9a except for the disappearance of $\mathrm{H}^{4}$ peak at $4.31 \mathrm{ppm}$ and simplification of proton splitting for $\mathrm{H}^{\prime}$ at $3.47 \mathrm{ppm}(\mathrm{d}, J=12.8 \mathrm{~Hz})$ and $\mathrm{H} 5 "$ at $3.51(\mathrm{~d}, J=12.8 \mathrm{~Hz})$ : MS (ESI) $m / z 228\left(\mathrm{MH}^{+}\right)$. 


\section{EPR Studies}

\subsection{Sample preparation and methods}

Following the well-established methodology of preparation of transparent homogeneous glassy samples, their irradiation and EPR studies as well as analyses of the EPR spectra in our laboratory, ${ }^{10-21}$ the homogeneous glassy samples of $\mathbf{1}$ to $\left.\mathbf{7}, \mathbf{2}^{\prime} \mathbf{- D}\right]-\mathbf{2},\left[\mathbf{3}^{\prime}-\mathbf{D}\right]-\mathbf{2},\left[\mathbf{4}^{\prime}-\mathbf{D}\right]-\mathbf{2},[\mathbf{5 , 6}-$ D,D]-2, and ${ }^{15} \mathrm{~N}$ incorporated azido group in 2 in $7.5 \mathrm{M} \mathrm{LiCl} / \mathrm{D}_{2} \mathrm{O}$ or $7.5 \mathrm{M} \mathrm{LiCl} / \mathrm{H}_{2} \mathrm{O}$ were made. Subsequently, these samples were $\gamma$-irradiated and EPR analyses of these samples were carried out.

Compounds purchased: 2'-AZdU (2) was obtained from Santa Cruz Biotechnology, CA, USA. 5'-azido-2',5'-dideoxyuridine (5) was procured from Carbosynth, UK. 3'-AZ-2',3'-ddU (3) and 3azido-1-propanol (3AZPrOH, 7) were purchased from Sigma-Aldrich (St. Louis, MO, USA). Lithium chloride ( $\mathrm{LiCl}$ ) (ultra dry, 99.995\% (metals basis)) was obtained from Alfa Aesar (Ward Hill, MA, USA). Deuterium oxide $\left(\mathrm{D}_{2} \mathrm{O}\right)$ (99.9 atom \% D) was purchased from Aldrich Chemical Company Inc. (Milwaukee, WI, USA). All compounds including the synthesized ones were used without further purification.

Glassy sample preparation:

(i) Preparation of homogeneous solutions: First, homogeneous solution was prepared by dissolving 0.5 to $5 \mathrm{mg} / \mathrm{mL}$ of a compound (e.g., 2) in either $7.5 \mathrm{M} \mathrm{LiCl}$ in $\mathrm{D}_{2} \mathrm{O}$ or in $\mathrm{H}_{2} \mathrm{O}$. The native $\mathrm{pH}$ of $7.5 \mathrm{M} \mathrm{LiCl}$ in $\mathrm{D}_{2} \mathrm{O}$ or in $\mathrm{H}_{2} \mathrm{O}$ is ca. 5 and $\mathrm{pH}$ of these solutions was not adjusted. ${ }^{20-24}$

(ii) Preparation of glassy samples and their storage: Homogenous solutions of $\mathbf{1}$ to $\left.\mathbf{7},\left[\mathbf{2}^{\prime}-\mathbf{D}\right]-\mathbf{2}, \mathbf{3} \mathbf{3}^{\prime}-\mathbf{D}\right]-\mathbf{2}$, [4'-D]-2, [5,6-D,D]-2, and ${ }^{15} \mathrm{~N}$ incorporated azido group in 2 were thoroughly bubbled with nitrogen gas. Subsequently, those solutions were immediately drawn into $4 \mathrm{~mm}$ Suprasil quartz tubes (Catalog no. 734-PQ-8, WILMAD Glass Co., Inc., Buena, NJ, USA). The quartz tubes containing these solutions were then rapidly immersed in liquid nitrogen $(77 \mathrm{~K})$. Owing to rapid cooling at $77 \mathrm{~K}$, the homogeneous liquid solutions formed transparent homogeneous glassy solutions. Homogeneous glassy solutions of these compounds were subsequently $\gamma$-irradiated at $77 \mathrm{~K}$ and then subjected to progressive annealing experiments during the EPR studies. All glassy samples were stored in the dark at $77 \mathrm{~K}$ in Teflon containers.

$\gamma$-Irradiation of glassy samples and their storage: As per our well-established methodology of $\gamma$-irradiation of glassy samples of DNA and RNA-models, ${ }^{10-21}$ the glassy samples were $\gamma\left({ }^{60} \mathrm{Co}\right)$-irradiated (absorbed dose $=375-500 \mathrm{~Gy}(1.5$ to $2 \mathrm{~h})$ ) at $77 \mathrm{~K}$ and stored at $77 \mathrm{~K}$ in Teflon containers in the dark. Owing to 0.5 to $10 \mathrm{mg}$ per $\mathrm{mL}$ of $7.5 \mathrm{M} \mathrm{LiCl}$ glass $\left(\mathrm{D}_{2} \mathrm{O}\right.$ or $\left.\mathrm{H}_{2} \mathrm{O}\right)$ and as per our previous work with $3^{\prime}$-AZT, ${ }^{21}$ the radiation-produced prehydrated electrons in the glass ${ }^{22-24}$ are scavenged by the solute $\left(\mathbf{1}\right.$ to $\mathbf{7},\left[\mathbf{2}^{\prime}-\mathbf{D}\right]-\mathbf{2}$, $\left[3^{\prime}-\mathbf{D}\right]-2,\left[4^{\prime}-\mathbf{D}\right]-2,[5,6-D, D]-2$, and ${ }^{15} \mathbf{N}$ incorporated azido group in 2 ) and $\mathrm{Cl}_{2}{ }^{\bullet}{ }^{-}$is formed owing to scavenging of radiation-induced holes by the matrix $(7.5 \mathrm{M} \mathrm{LiCl})$. 
Annealing of glassy samples: As per our previous studies, ${ }^{10-21}$ a variable temperature assembly that passed liquid nitrogen cooled dry nitrogen gas past a thermister and over the glassy sample was employed for annealing. Stepwise (either $5 \mathrm{~K}$ or $10 \mathrm{~K}$ step) annealing of each glassy sample was conducted in the range $(140-170) \mathrm{K}$ for $15 \mathrm{~min}$. The matrix radical, $\mathrm{Cl}_{2}{ }^{-}$, did not react with sample. As a result, we were able to study formation of $\mathrm{RNH} \bullet$ via reaction of radiation-produced prehydrated electron with the compound (1 to 7, [2'-D]-2, [3'-D]-2, [4'-D]-2, [5,6-D,D $]-2$, and ${ }^{15} \mathbf{N}$ incorporated azido group in 2 ) and subsequent reactions of $\mathrm{RNH} \bullet$ directly via EPR spectroscopy.

Electron Paramagnetic Resonance: Following our ongoing studies on DNA and RNA-radicals, ${ }^{10-21}$ we used a Varian Century Series X-band $(9.3 \mathrm{GHz})$ EPR spectrometer with an E-4531 dual cavity, 9-inch magnet, and a $200 \mathrm{~mW}$ Klystron. For the field calibration, Fremy's salt $\left(g_{\text {center }}=2.0056, \boldsymbol{A}(\mathrm{N})=13.09 \mathrm{G}\right)$ was employed. All EPR spectra were recorded at $77 \mathrm{~K}$, at $45 \mathrm{~dB}(6.3 \mu \mathrm{W})$ as well as $40 \mathrm{~dB}(20 \mu \mathrm{W})$, at the central field $=3300 \mathrm{G}$, and at the microwave frequency $=9.3 \mathrm{GHz}$. Using Fremy's salt field calibration $\left(g_{\text {center }}=2.0056, \boldsymbol{A}(\mathrm{N})=13.09 \mathrm{G}\right)$ and the central field, the total hyperfine splitting of the experimentally recorded spectrum, the individual HFCC values, and the $g$-value of the radical (aminyl or iminyl) are determined. We note here that recording of EPR spectra at $77 \mathrm{~K}$ maximizes the signal height and allows for comparison of signal intensities at the same temperature.

As evident from the results presented in section B.1 in the main manuscript, the hyperfine couplings seen in the experimentally recorded spectra of $\mathrm{RNH} \bullet$ arise from the axially symmetric anisotropic ${ }^{14} \mathrm{~N}$, the isotropic $\beta$-proton $\left(\mathrm{H} 2^{\prime}\right)$, and the anisotropic $\alpha \mathrm{H} / \alpha \mathrm{D}$ of the exchangeable NH/ND. Employing the Bruker programs (WIN-EPR and SimFonia) and following our ongoing studies on DNA and RNA-radicals, ${ }^{10-21}$ anisotropic simulations of experimentally recorded EPR spectra of various radicals were carried out using the experimentally obtained hyperfine coupling constant (HFCC) values and $g$-values. The EPR parameters (e.g., HFCC values, linewidth, etc.) were adjusted to obtain the "best fit" simulated spectrum that matched the experimental EPR spectrum well. ${ }^{10-24}$ In addition, each EPR spectrum reported in the main manuscript as well as in the supporting information is obtained after subtraction of line components due to $\mathrm{Cl}_{2} \cdot{ }^{-}$.

Method of theoretical calculations: The geometries of radicals were first optimized as implemented in the Gaussian 09 suit of program using the DFT/B3LYP/6-31G** method. ${ }^{25}$ Employing optimized geometries of these radicals, spin densities were subsequently plotted; energies of radicals and hyperfine coupling constant (HFCC) values were calculated using DFT/B3LYP/6-31G** method (vide infra) in Gaussian 09. Theoretically predicted HFCC values obtained employing B3LYP/6-31G** method agree well with those obtained using experiment. ${ }^{10-24,26} \mathrm{Jmol}$ molecular modeling freeware was used to plot optimized molecular structures. ${ }^{27}$ 


\subsection{Additional EPR Spectra (Figures S1-S12)}

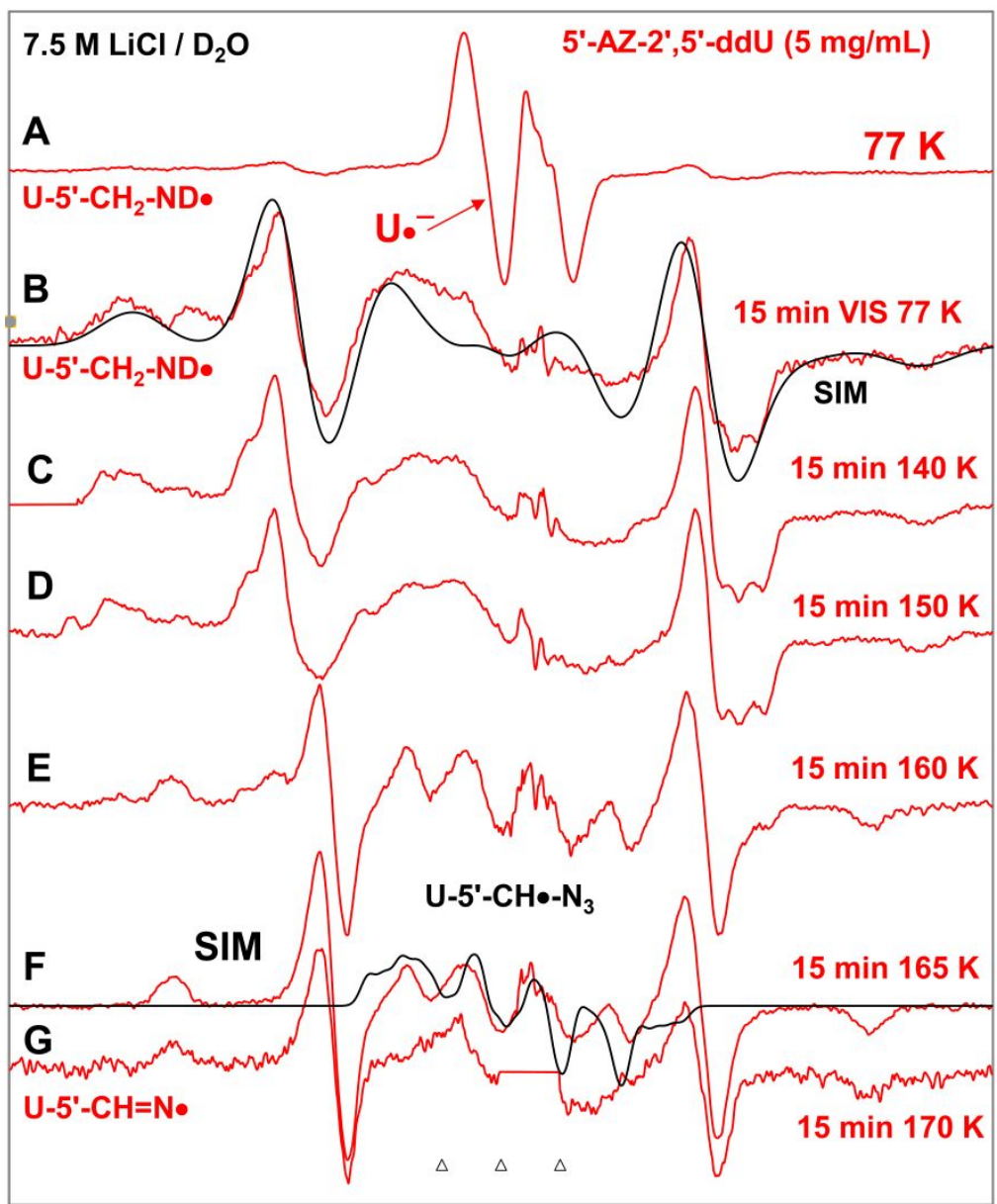

Figure S1. Spectra (A-D) in red were obtained from samples of $5^{\prime}-A Z-2 ', 5^{\prime}-d d U(5)([5]=5 \mathrm{mg} / \mathrm{mL})$ by subtraction of line components of $\mathrm{Cl}_{2}{ }^{-}$spectrum (ref. 47 in the main manuscript) from the individual experimentally recorded spectrum. (A) EPR spectrum after radiation-produced prehydrated one-electron addition at $77 \mathrm{~K}$ in $7.5 \mathrm{M} \mathrm{LiCl} / \mathrm{D}_{2} \mathrm{O}$. Spectrum $(\mathrm{B}$, red) was obtained after 15 min photoexcitation by a photoflood lamp at $77 \mathrm{~K}$. Spectra $(\mathrm{C})$ to $(\mathrm{G})$ were obtained via stepwise annealing of the sample for 15 $\mathrm{min}$ at, 140, 150, 160, 165, and $170 \mathrm{~K}$. All spectra were recorded at $77 \mathrm{~K}$. Sum of two isotropic $\beta$-proton couplings (ca. 90.5 G) is assigned to the central doublet found in spectra (A) to (D); the large central doublet (ca. $82 \mathrm{G}$ ) in spectra (E to $\mathrm{G}$, red) is due to one isotropic $\beta$-proton coupling. Whereas, the wings in spectra (A) to $(\mathrm{G})$ show the $\boldsymbol{A}_{\mathrm{zz}}$ components of the anisotropic nitrogen hyperfine coupling. All spectra were recorded at $77 \mathrm{~K}$. The black spectra in (B) and (F) are the simulated spectra. Spectrum (G) is the spectrum shown in Figure 1(F) in the main manuscript and in Figure S2 after subtraction of the central quartz spike.

The three reference markers (open triangles) in this Figure and in other Figures show the position of Fremy's salt resonance with the central marker at $\mathrm{g}=2.0056$. Each of these markers is separated from each other by $13.09 \mathrm{G}$.

Simulation of black spectrum in (B) (also, Figure 4(B) in the main manuscript): To simulate the black spectrum in Figure S1(B), we have taken a set of two $\beta$ H-couplings (e.g., (44+46.5) G, (34+56.5) G, and 
$(24+66.5) \mathrm{G})$ so that the sum of the two $\beta$-proton couplings is ca. $90.5 \mathrm{G}$, the same anisotropic nitrogen hyperfine couplings $\left(\boldsymbol{A}_{\|}\left(\boldsymbol{A}_{z z}\right)\right.$ of $\left.c a .42 .5 \mathrm{G}, \boldsymbol{A}_{\perp}\left(\boldsymbol{A}_{x x}=\boldsymbol{A}_{y y}=0\right)\right)$, an $\alpha$-D coupling $(4.5,0,6) \mathrm{G}$ due to the exchangeable $\mathrm{N}-\mathrm{H}$ proton of the aminyl radical from our previous works (ref. 7 to 9 in the main manuscript) and with $g_{\|}=2.0020$ and $g_{\perp}=2.0043$. With these parameters, and taking the linewidths as (12, 9, 9) $\mathrm{G}$ and lineshape with a mixed Lorentzian/Gaussian = 1, we have simulated a spectrum (black).

The simulation parameters of the simulated (black) spectrum in Figures S1(F) are mentioned in Table 1.

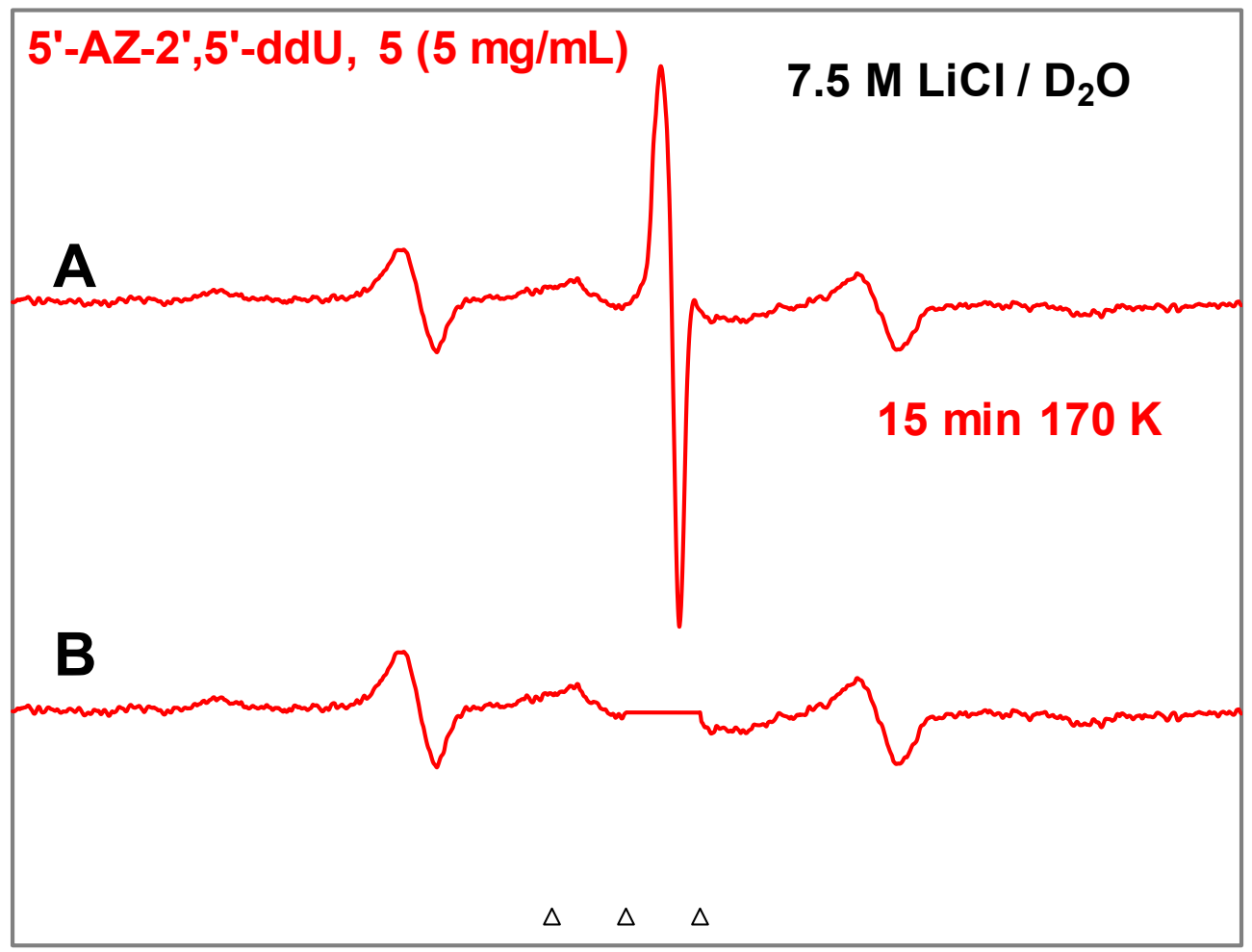

Figure S2. Spectrum (A) is the originally recorded experimental spectrum of Figure $1(\mathrm{~F})$ in the main manuscript showing the central quartz spike. Spectrum (B) is the spectrum shown in Figure 1(F) after elimination of the central quartz spike. 


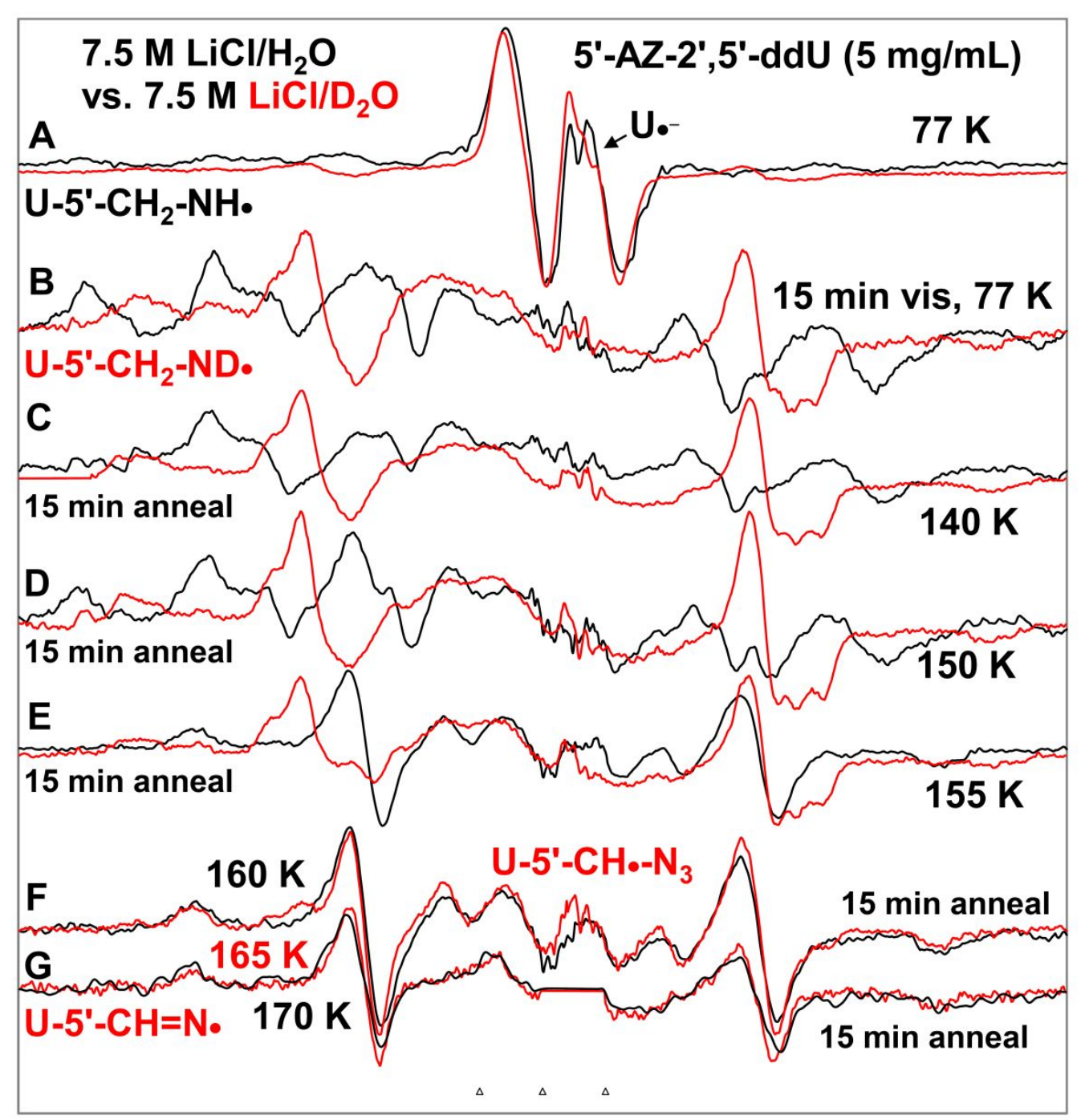

Figure S3. Comparison of EPR spectral data from matched samples of 5'-AZ-2',5'-ddU 5, (5 mg/mL) with different matrices (7.5 M LiCl/ $\mathrm{H}_{2} \mathrm{O}$ (black) and $7.5 \mathrm{M} \mathrm{LiCl} / \mathrm{D}_{2} \mathrm{O}$ (red)). Spectra (A-D) were obtained by subtraction of line components of $\mathrm{Cl}_{2}{ }^{-}$spectrum (see Figure $\mathrm{S} 1$ ) from the individual experimentally recorded spectrum. (A) EPR spectra after radiation-produced prehydrated one-electron addition to 5'-AZ2',5'-ddU at $77 \mathrm{~K}$. Spectrum (B) was obtained after $15 \mathrm{~min}$ photoexcitation by a photoflood lamp at $77 \mathrm{~K}$. Spectra $(\mathrm{C})$ to $(\mathrm{G})$ were obtained via stepwise annealing of the sample for $15 \mathrm{~min}$ at 140, 150, 160, 165, and $170 \mathrm{~K}$. All spectra were recorded at $77 \mathrm{~K}$. Sum of two isotropic $\beta$-proton couplings is assigned to the central doublet found in spectra (A) to $(\mathrm{G})$; whereas, the wings in spectra (A) to (G) show the $\boldsymbol{A}_{\mathrm{zz}}$ components of the anisotropic nitrogen hyperfine coupling. Similar to Figure S2, the central quartz spike has been removed in the red spectrum in Figure 1(G). All spectra were recorded at $77 \mathrm{~K}$. 


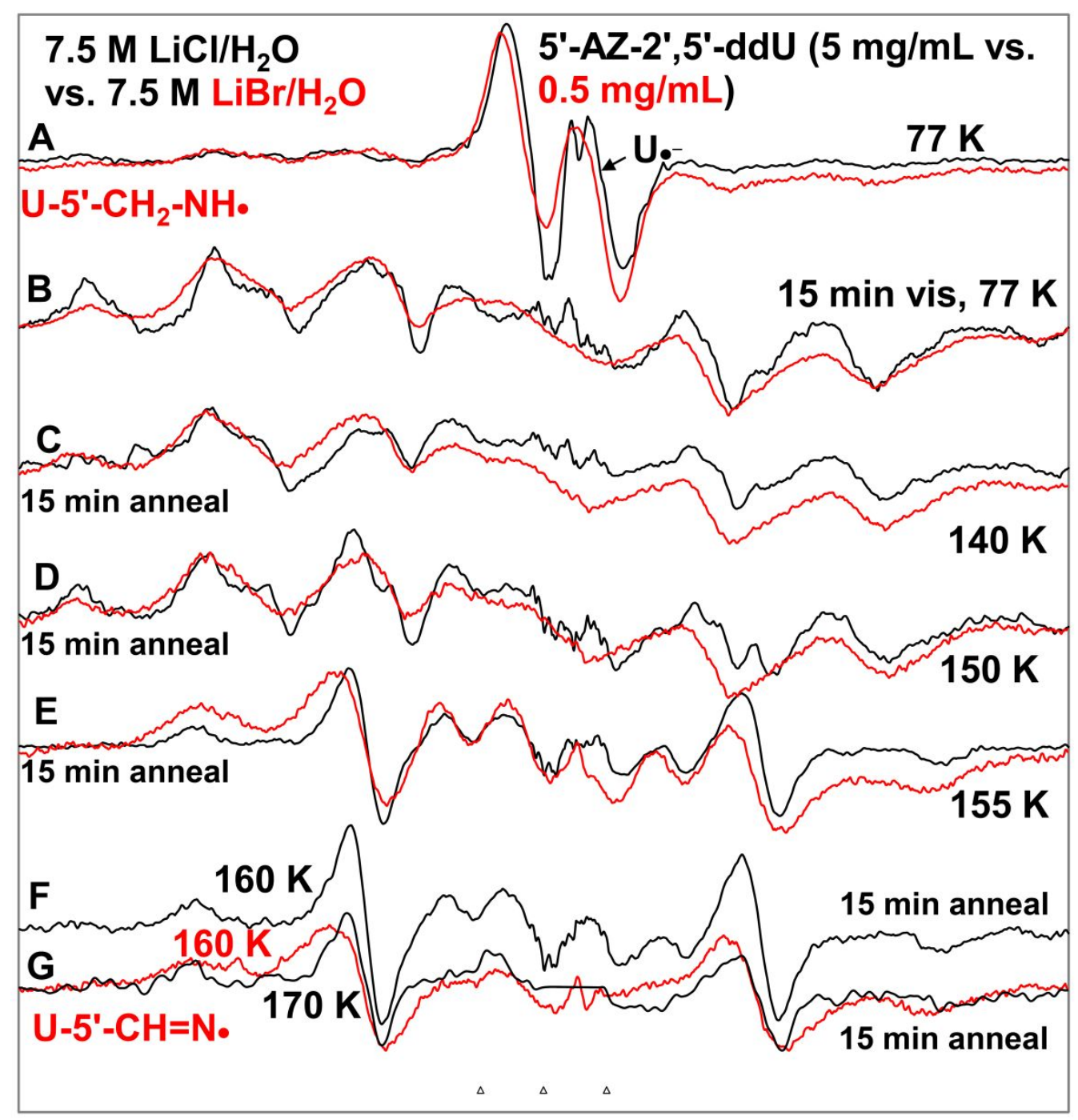

Figure S4. Comparison of EPR spectral data from samples of $5^{\prime}$-AZ-2',5'-ddU $5(5 \mathrm{mg} / \mathrm{mL}$ in $7.5 \mathrm{M}$ $\mathrm{LiCl} / \mathrm{H}_{2} \mathrm{O}$, black) with those samples of 5'-AZ-2',5'-ddU $\left(0.5 \mathrm{mg} / \mathrm{mL}\right.$ in $7.5 \mathrm{M} \mathrm{LiBr} / \mathrm{H}_{2} \mathrm{O}$, red). Spectra (AD) were obtained by subtraction of line components of $\mathrm{Cl}_{2}{ }^{-}$spectrum (see Figure S1) from the individual experimentally recorded spectrum. (A) EPR spectra after radiation-produced prehydrated one-electron addition to $5^{\prime}$-AZ-2',5'-ddU at $77 \mathrm{~K}$. Spectrum (B) was obtained after 15 min photoexcitation by a photoflood lamp at $77 \mathrm{~K}$. Spectra $(\mathrm{C})$ to $(\mathrm{G})$ were obtained via stepwise annealing of the sample for 15 min at 140,150,160, 165, and $170 \mathrm{~K}$. All spectra were recorded at $77 \mathrm{~K}$. Sum of two isotropic $\beta$-proton couplings is assigned to the central doublet found in spectra (A) to (G); whereas, the wings in spectra (A) to $(\mathrm{G})$ show the $\boldsymbol{A}_{\mathrm{zz}}$ components of the anisotropic nitrogen hyperfine coupling. Similar to Figure S2, the central quartz spike has been removed in the red spectrum in Figure 1(G). All spectra were recorded at 77 $\mathrm{K}$. 


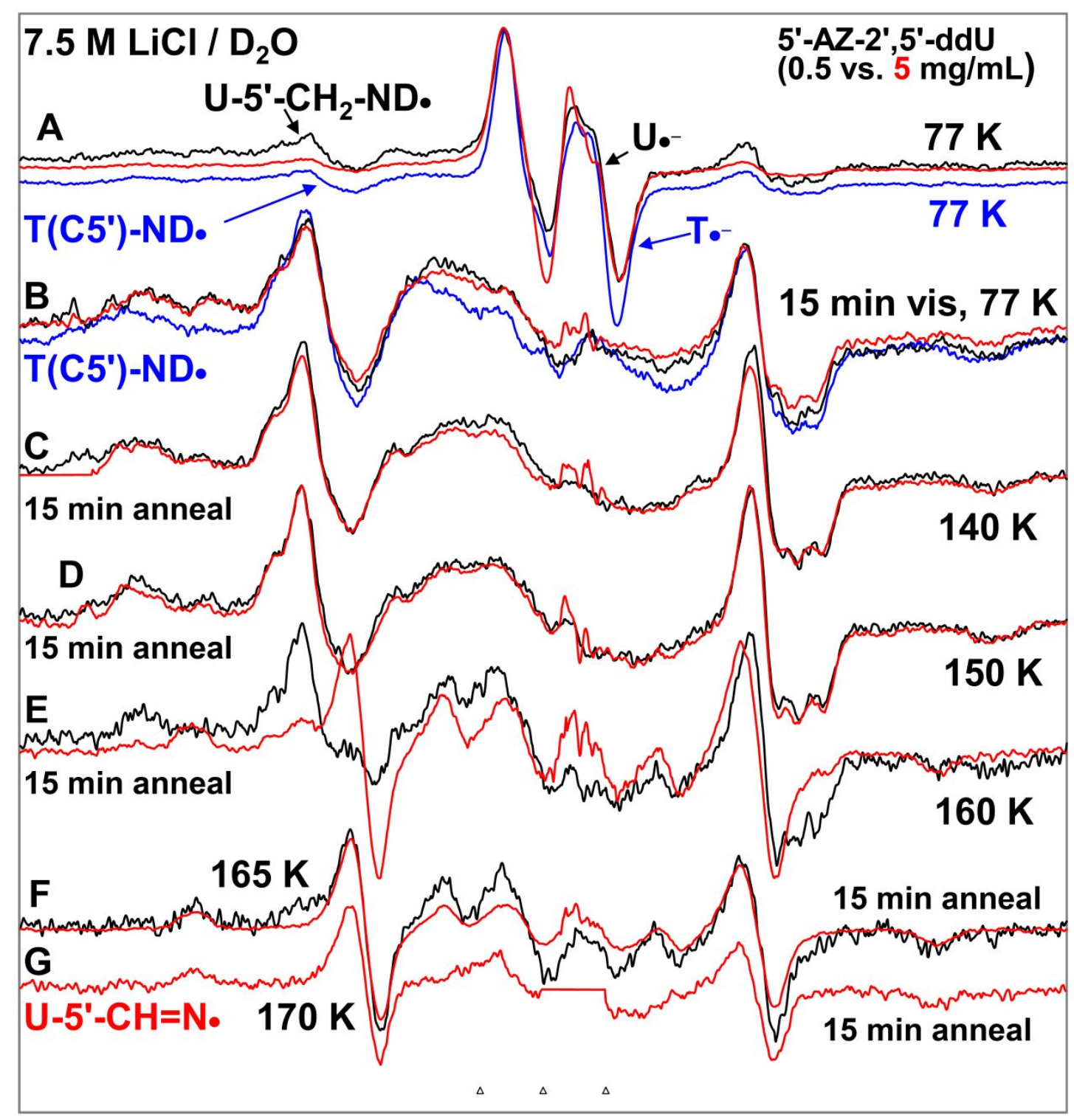

Figure S5. Comparison of EPR spectral data from samples of 5'-AZ-2',5'-ddU, 5, with different concentrations $(0.5 \mathrm{mg} / \mathrm{mL}$ (black) and $5 \mathrm{mg} / \mathrm{mL}$ (red)). Spectra (A-D) were obtained by subtraction of line components of $\mathrm{Cl}_{2}{ }^{-}$spectrum (see Figure S1) from the individual experimentally recorded spectrum. (A) EPR spectra after radiation-produced prehydrated one-electron addition to 5'-AZ-2',5'-ddU at $77 \mathrm{~K}$ in 7.5 M LiCl/ $\mathrm{D}_{2} \mathrm{O}$. Spectrum (B) was obtained after 15 min photoexcitation by a photoflood lamp at $77 \mathrm{~K}$. Spectra $(C)$ to $(G)$ were obtained via stepwise annealing of the sample for $15 \mathrm{~min}$ at $140,150,160,165$, and $170 \mathrm{~K}$. All spectra were recorded at $77 \mathrm{~K}$. Sum of two isotropic $\beta$-proton couplings is assigned to the central doublet found in spectra (A) to $(\mathrm{G})$; whereas, the wings in spectra (A) to (G) show the $\boldsymbol{A}_{\mathrm{zz}}$ components of the anisotropic nitrogen hyperfine coupling. Similar to Figure S2, the central quartz spike has been removed in the red spectrum in Figure $1(\mathrm{G})$. All spectra were recorded at $77 \mathrm{~K}$. The experimental spectra of $\mathrm{T}\left(\mathrm{C}^{\prime}\right)$-ND from $5^{\prime}$-AZT (blue, see ref. 8 in the main manuscript) are superimposed in (A) and (B) for comparison. 


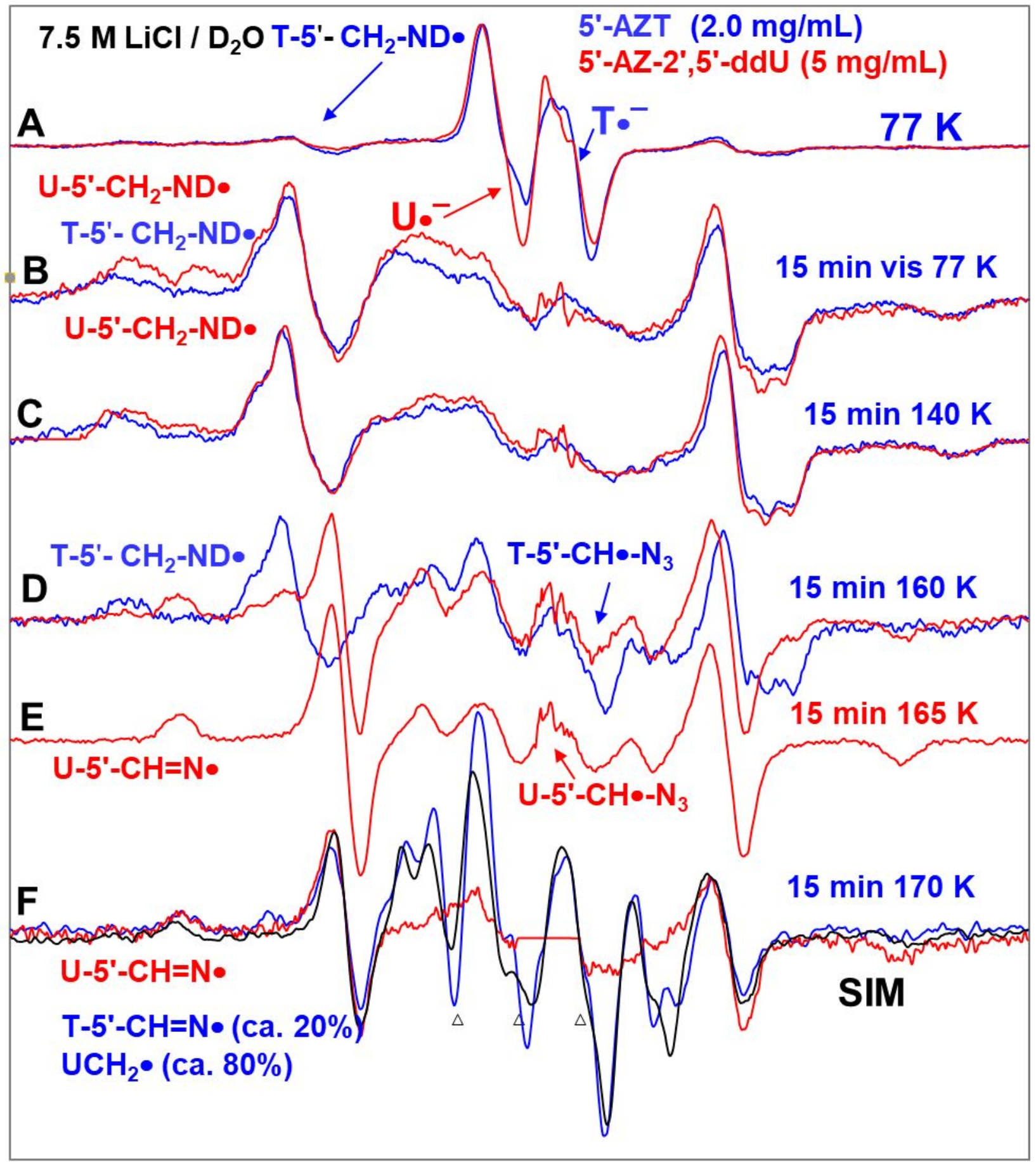

Figure S6. Comparison of EPR spectral data from samples of $5^{\prime}-\mathrm{AZ}-2^{\prime}, 5^{\prime}-\mathrm{ddU} 5(5 \mathrm{mg} / \mathrm{mL}$ in $7.5 \mathrm{M}$ $\mathrm{LiCl} / \mathrm{H}_{2} \mathrm{O}$, red) with those samples of $5^{\prime}-\mathrm{AZT}\left(2.0 \mathrm{mg} / \mathrm{mL}\right.$ in $7.5 \mathrm{M} \mathrm{LiCl} / \mathrm{D}_{2} \mathrm{O}$, blue). Spectra (A-C) were obtained by subtraction of line components of $\mathrm{Cl}_{2}{ }^{-}$spectrum (see Figure S1) from the individual experimentally recorded spectrum. (A) EPR spectra after radiation-produced prehydrated one-electron addition to $5^{\prime}$-AZ-2',5'-ddU at $77 \mathrm{~K}$. Spectrum (B) was obtained after 15 min photoexcitation by a photoflood lamp at $77 \mathrm{~K}$. Spectra (C) to (F) were obtained via stepwise annealing of the sample for 15 
min at 140, 160, 165, and $170 \mathrm{~K}$. All spectra were recorded at $77 \mathrm{~K}$. Sum of two isotropic $\beta$-proton couplings is assigned to the central doublet found in spectra (A) to (D); whereas, the wings in spectra (A) to $(\mathrm{G})$ show the $\boldsymbol{A}_{\mathrm{zz}}$ components of the anisotropic nitrogen hyperfine coupling. Similar to Figure S2, the central quartz spike has been removed in the red spectrum in Figure 1(F). All spectra were recorded at 77 $\mathrm{K}$. The black spectrum in Figure (F) is the simulated spectrum obtained by adding the $80 \%$ of the spectrum of the allylic radical, $\mathrm{UCH}_{2} \bullet$ (see ref. 8 in the main manuscript) and $20 \%$ of the sigma-type iminyl radical $(\mathrm{R}=\mathrm{N} \bullet$ ) from AmdU (see Figure 1 and ref. 8 in the main manuscript). $\mathrm{R}=\mathrm{N} \bullet$ spectrum from AmdU and $\mathrm{UCH}_{2} \bullet$ spectrum are treated as benchmarks; the simulated spectrum has been superimposed on the blue spectrum of 5'-AZT sample in Figure (F) for comparison. 


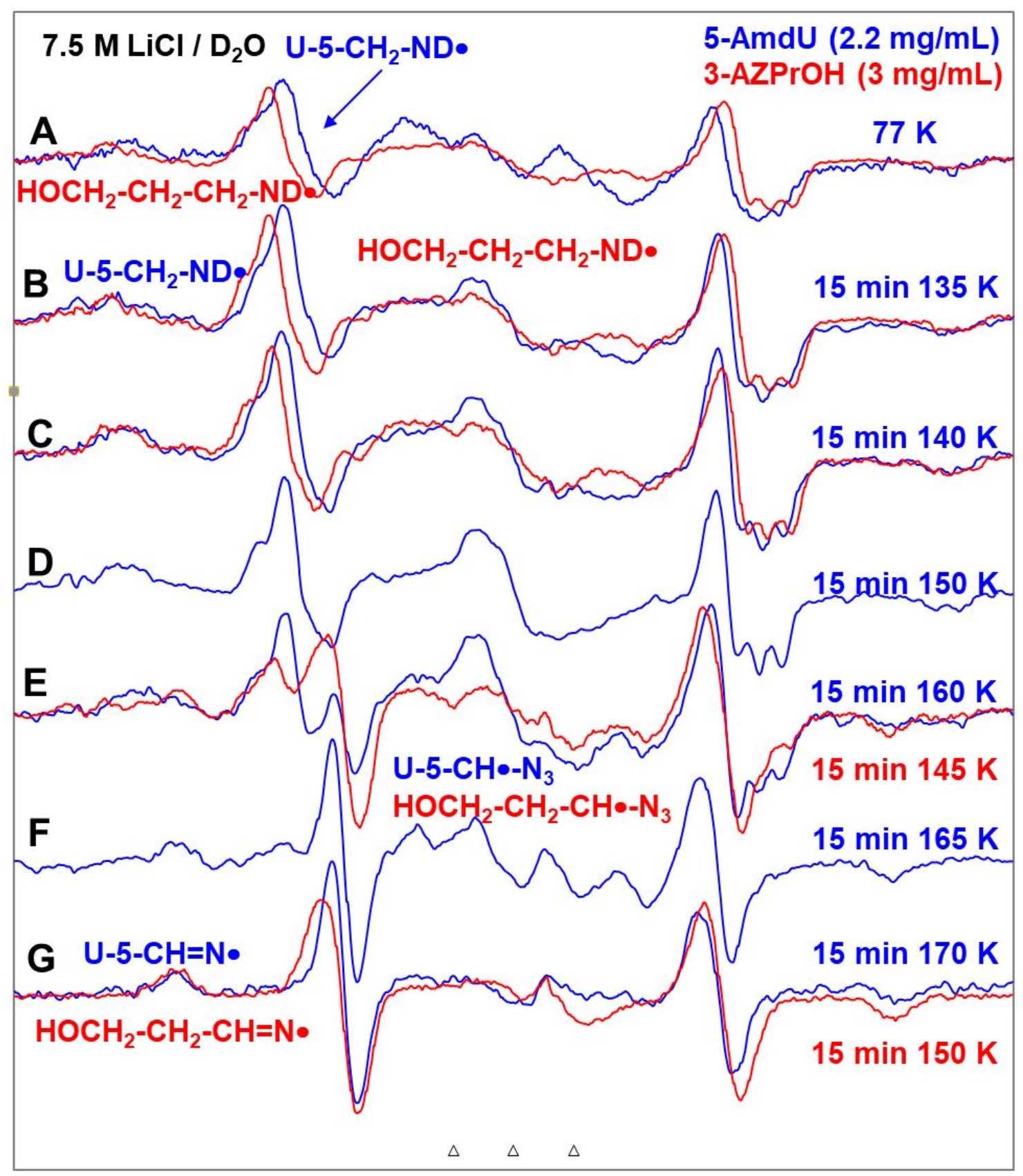

Figure S7. Spectra (A-C) in red were obtained from samples of 3-azidopropanol, 3-AZPrOH ([3AZPrOH] $=3 \mathrm{mg} / \mathrm{mL}$ ) by subtraction of line components of $\mathrm{Cl}_{2}{ }^{-}$spectrum (Figure S1) from the individual experimentally recorded spectrum. (A) ERR spectrum (red) after radiation-produced prehydrated one-electron addition to the same sample of 3-AZPrOH at $77 \mathrm{~K}$ in $7.5 \mathrm{M} \mathrm{LiCl} / \mathrm{D}_{2} \mathrm{O}$. Spectra $\mathrm{C}$ (red) to $\mathrm{G}$ (red) were obtained via stepwise annealing of the sample for $15 \mathrm{~min}$ at $135,140,145$, and $150 \mathrm{~K}$. All spectra were recorded at $77 \mathrm{~K}$. Sum of two isotropic $\beta$-proton couplings is assigned to the large central doublet found in red spectra (A) to (D); the large central doublet (ca. $82 \mathrm{G}$ ) in spectra (E to G, red) is due to one isotropic $\beta$-proton coupling. Whereas, the wings in spectra (A) to (G) show the $\boldsymbol{A}_{\mathrm{zz}}$ components of the anisotropic nitrogen hyperfine coupling. All spectra were recorded at $77 \mathrm{~K}$. The 
experimental spectra from AmdU from ref. 7 (2.2 $\mathrm{mg} / \mathrm{mL}$, blue) are superimposed in (A) to (G) for comparison.

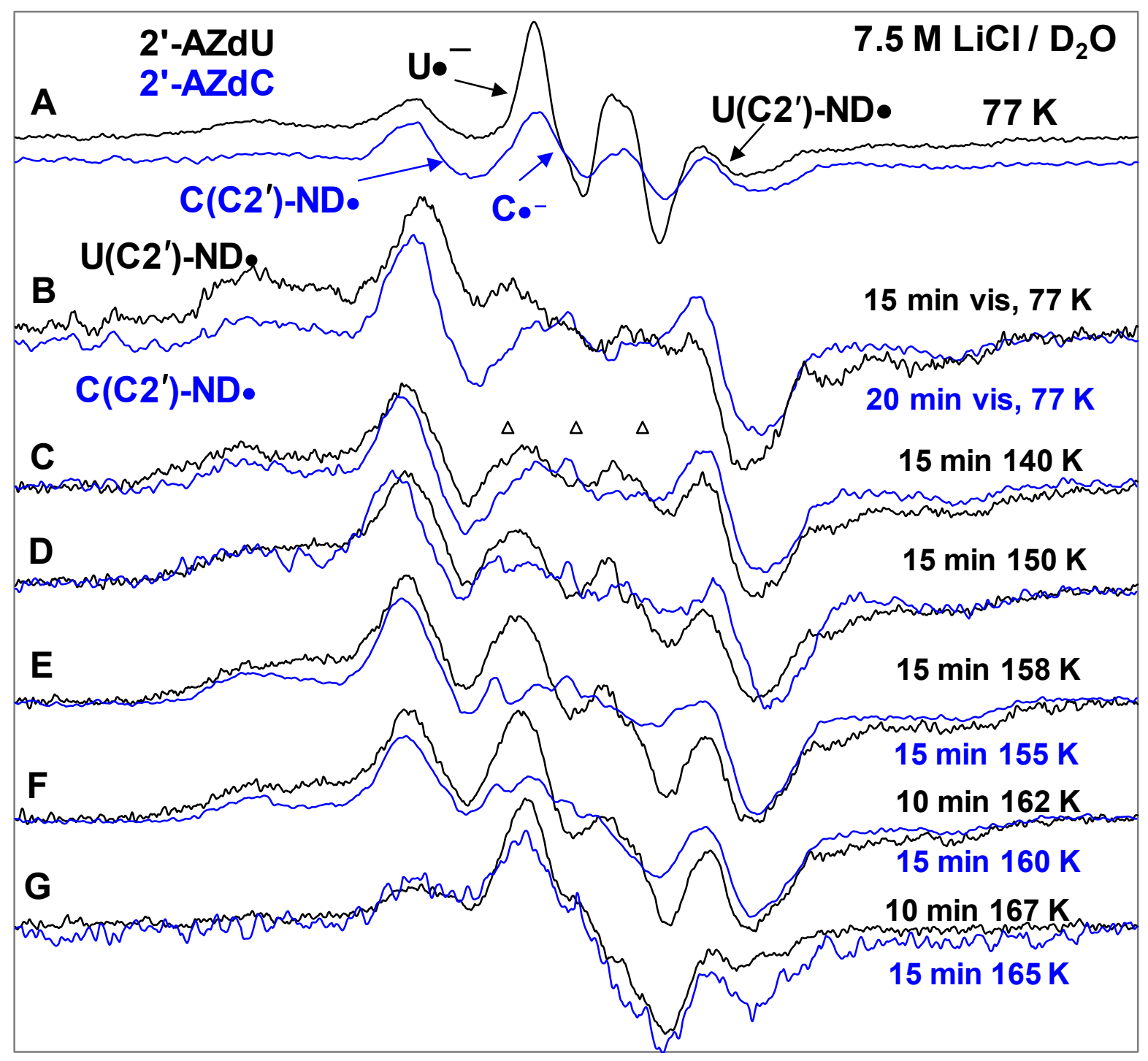

Figure S8. EPR spectra of matched samples of 2'-AZdU (black) $(2 \mathrm{mg} / \mathrm{mL})$ and the in-house synthesized 2'-AZdC (blue) $(2 \mathrm{mg} / \mathrm{mL})$ at the native $\mathrm{pD}(\mathrm{ca} .5)$ of the homogeneous glassy solution of $7.5 \mathrm{M} \mathrm{LiCl}$ in $\mathrm{D}_{2} \mathrm{O}$. (A) After $\gamma$-irradiation (absorbed dose $=500 \mathrm{~Gy}$ ) produced oneelectron addition at $77 \mathrm{~K}$. (B) After visible illumination of samples employing a photoflood lamp at $77 \mathrm{~K}$ for 15 to 20 minutes. The central doublet in both spectra due to the uracil anion radical $\left(\mathrm{U}^{-}\right)$and cytosine anion radical $\left(\mathrm{C}^{-}\right)$are removed by photoejection of the excess electron. Spectra $(C)$ to $(G)$ are obtained after subsequent annealing for 10 to $15 \mathrm{~min}$ in the dark from ca. 140 to ca. $167 \mathrm{~K}$. All EPR spectra shown in Figures A to G were recorded at $77 \mathrm{~K}$. 


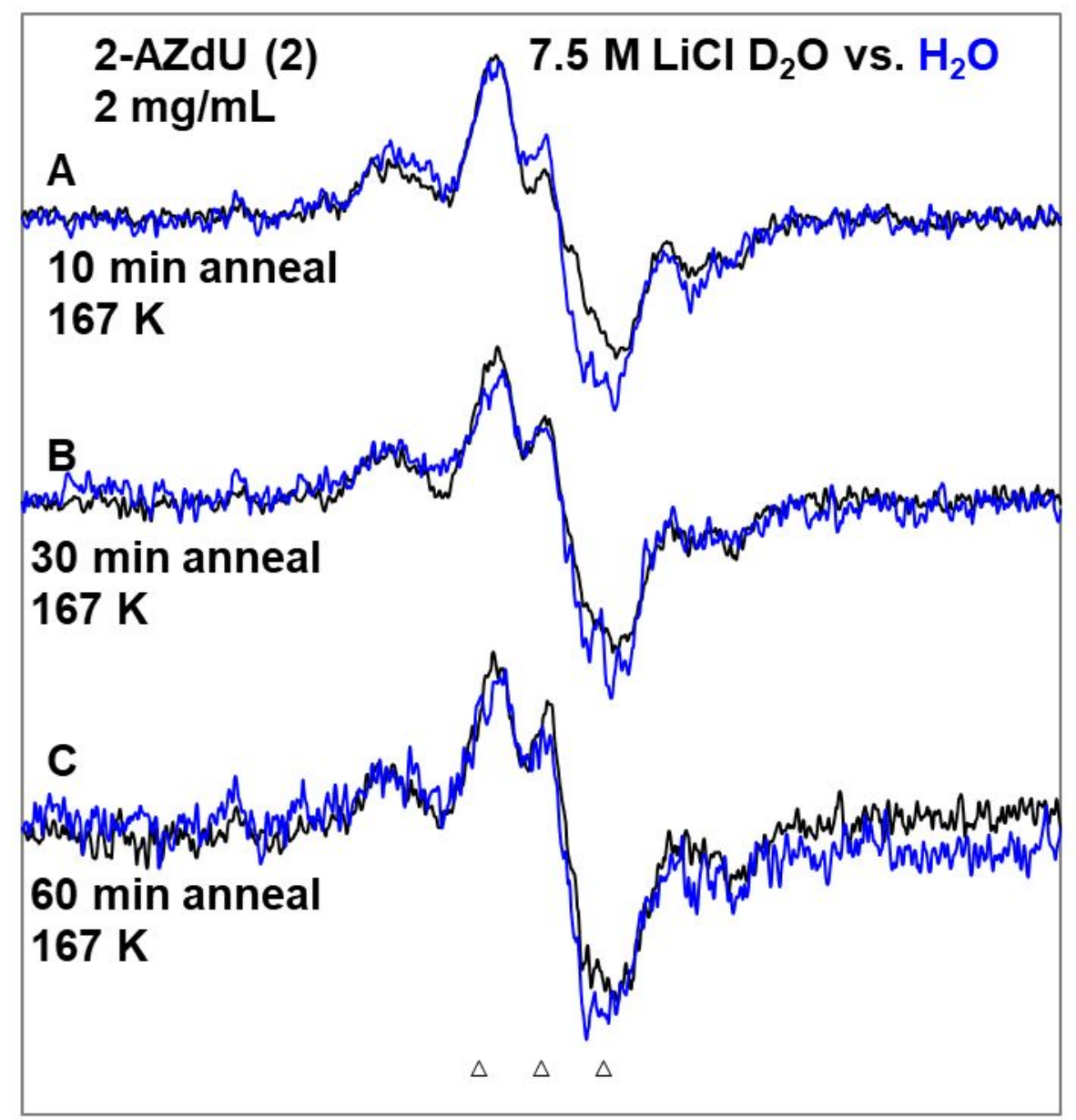

Figure S9. EPR spectra of matched samples of 2'-AZdU $(2 \mathrm{mg} / \mathrm{mL})$ in $7.5 \mathrm{M} \mathrm{LiCl} / \mathrm{D}_{2} \mathrm{O}$ (black) in $7.5 \mathrm{M} \mathrm{LiCl} / \mathrm{H}_{2} \mathrm{O}$ (blue) (A) After $\gamma$-irradiation (absorbed dose $=500 \mathrm{~Gy}$ ) produced oneelectron addition at $77 \mathrm{~K}$ and subsequently $10 \mathrm{~min}$ anneal at ca. $167 \mathrm{~K}$ in the dark. (B) After subsequent annealing for $30 \mathrm{~min}$ in the dark at ca. $167 \mathrm{~K}$. (C) After subsequent annealing for 60 min in the dark at ca. $167 \mathrm{~K}$. All EPR spectra were recorded at $77 \mathrm{~K}$. 


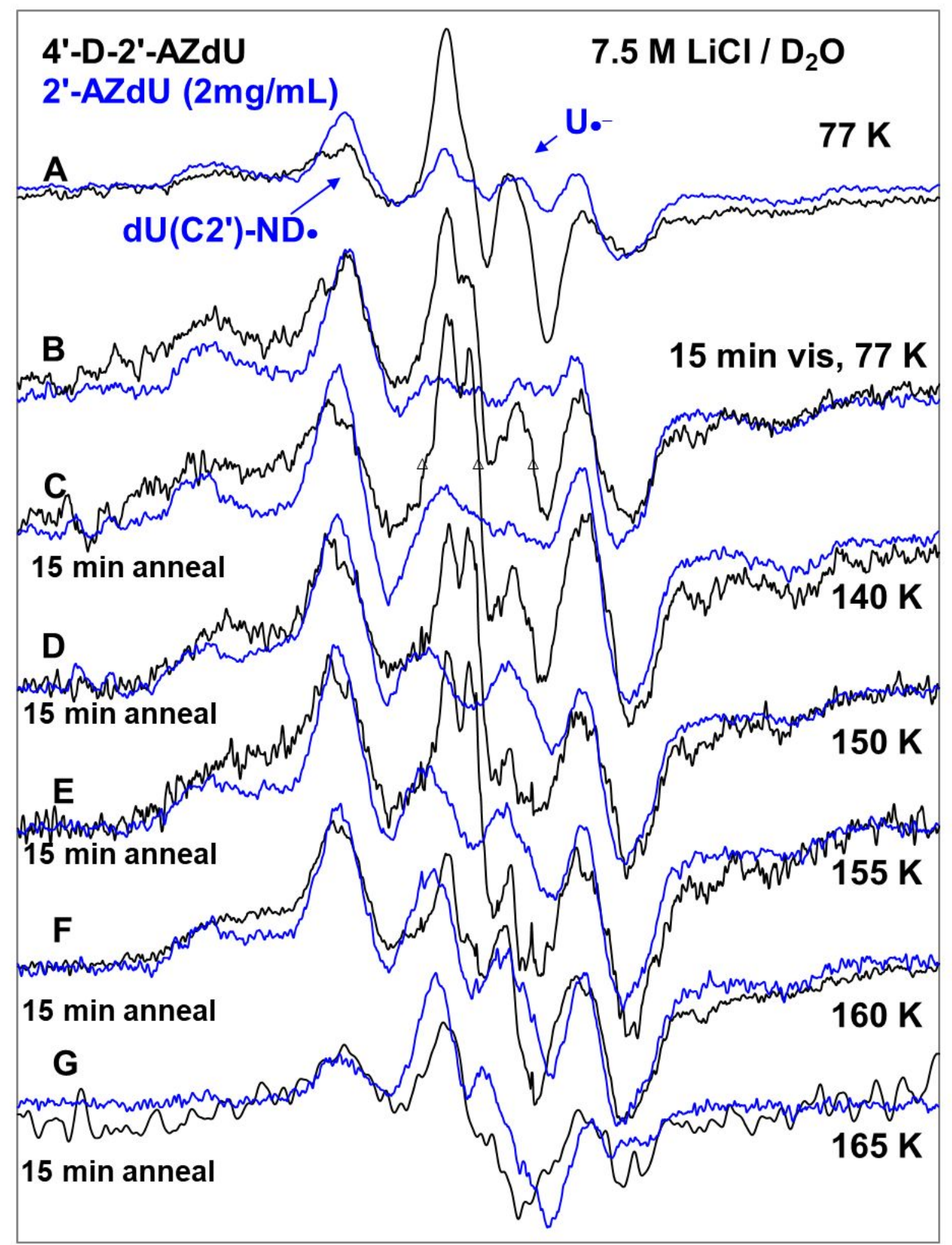

Figure S10. EPR spectra of matched samples of 2'-AZdU (black) $(2 \mathrm{mg} / \mathrm{mL})$ and the in-house synthesized [4'-D]-2 (blue) $(2 \mathrm{mg} / \mathrm{mL})$ at the native $\mathrm{pD}(\mathrm{ca} .5)$ of the homogeneous glassy 
solution of 7.5 $\mathrm{M} \mathrm{LiCl}$ in $\mathrm{D}_{2} \mathrm{O}$. (A) After $\gamma$-irradiation (absorbed dose $=500 \mathrm{~Gy}$ ) produced oneelectron addition at $77 \mathrm{~K}$. (B) After visible illumination of samples employing a photoflood lamp at $77 \mathrm{~K}$ for 15 to 20 minutes. The central doublet in both spectra due to the uracil anion radical $\left(\mathrm{U}^{-}{ }^{-}\right)$removed by photo-ejection of the excess electron. Spectra (C) to (G) are obtained after subsequent annealing for 10 to $15 \mathrm{~min}$ in the dark from ca. 140 to ca.167 K. All EPR spectra shown in Figures A to $\mathrm{G}$ were recorded at $77 \mathrm{~K}$.

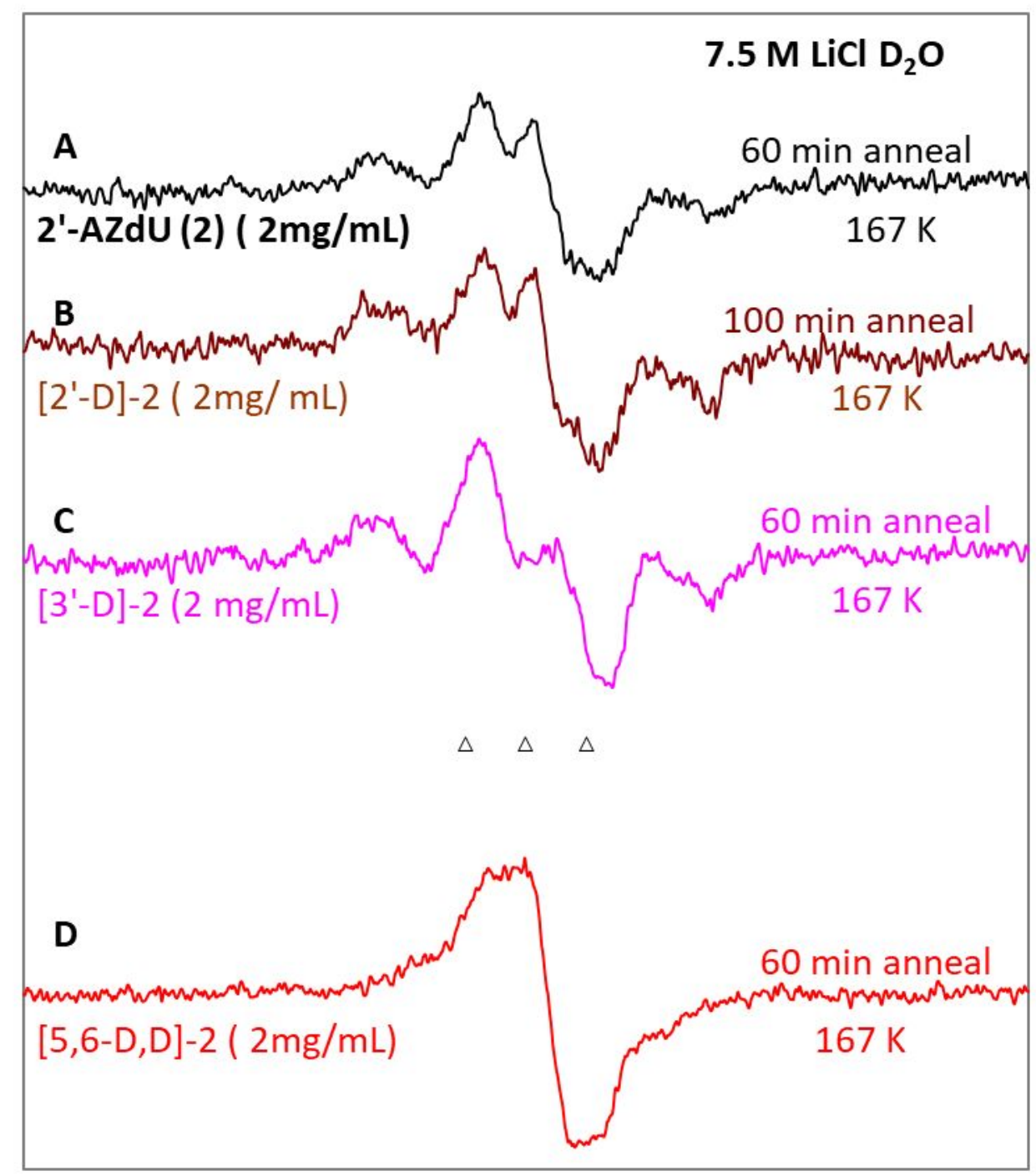

Figure S11. EPR spectra of matched samples of $2^{\prime}-\mathrm{AZdU}(2)(2 \mathrm{mg} / \mathrm{mL})$ in $7.5 \mathrm{M} \mathrm{LiCl} / \mathrm{D}_{2} \mathrm{O}$ (black) and [2'-D]-2 (brown), [3'-D]-2 (pink), and [5,6-D,D]-2 (red, also see Figure S12) in 7.5 $\mathrm{M} \mathrm{LiCl} / \mathrm{D}_{2} \mathrm{O}$ After $\gamma$-irradiation (absorbed dose $=500 \mathrm{~Gy}$ ) produced one-electron addition at 77 $\mathrm{K}$ and subsequently 60 to $100 \mathrm{~min}$ anneal at ca. $167 \mathrm{~K}$ in the dark. All EPR spectra were recorded at $77 \mathrm{~K}$. 


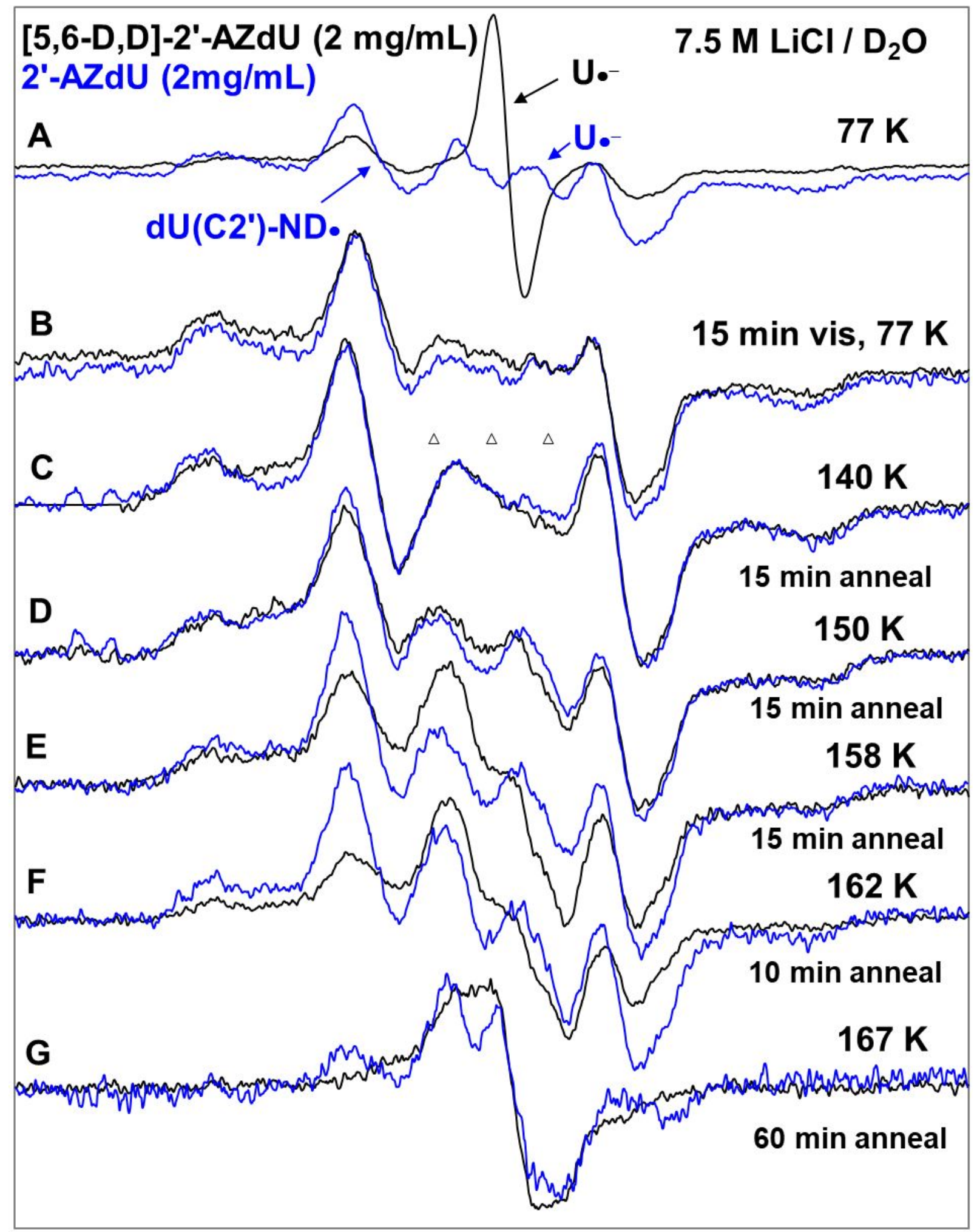

Figure S12. EPR spectra of matched samples of 2'-AZdU (2) (black) $(2 \mathrm{mg} / \mathrm{mL})$ and the inhouse synthesized [5,6-D,D]-2 (blue) $(2 \mathrm{mg} / \mathrm{mL})$ at the native $\mathrm{pD}(c a .5)$ of the homogeneous 
glassy solution of 7.5 M LiCl in $\mathrm{D}_{2} \mathrm{O}$. (A) After $\gamma$-irradiation (absorbed dose $=500 \mathrm{~Gy}$ ) produced one-electron addition at $77 \mathrm{~K}$. (B) After visible illumination of samples employing a photoflood lamp at $77 \mathrm{~K}$ for 15 to 20 minutes. The central doublet in both spectra due to the uracil anion radical $\left(\mathrm{U}^{-}\right)$removed by photoejection of the excess electron. [5,6-D,D]-2 is completely deuterated as the central doublet due to the uridine anion radical collapses to a singlet. It is the H-6 proton that gives the doublet spectrum in Figure 1A. Thus, the collapse to the singlet shows that H6 is fully deuterated.

Spectra $(\mathrm{C})$ to $(\mathrm{G})$ are obtained after subsequent annealing for 10 to $15 \mathrm{~min}$ in the dark from ca. 140 to ca.167 K. All EPR spectra shown in Figures A to G were recorded at $77 \mathrm{~K}$.

Via progressive annealing from $150 \mathrm{~K}$ up to $162 \mathrm{~K}$ (spectra shown in $\mathrm{C}$ to $\mathrm{F}$ ), we find that owing to the softening of the glass caused by the increase in the temperature, $\mathrm{dU}\left(\mathrm{C} 2^{\prime}\right)-\mathrm{ND}$ migrates and reacts with a [5,6-D,D]-2 molecule in its proximity. The spectra shown in Figure $\mathrm{G}$ show that the final radical formed via bimolecular reaction of the dU(C2')-ND・ with an unreacted [5,6-D,D]-2 leads to the formation of a C-centered radical (the radical site is at the C5or C6 site of the C5-C6 double bond in uridine) since the $\mathrm{dU}\left(\mathrm{C} 2{ }^{\prime}\right)-\mathrm{ND} \cdot$ may add to the $\mathrm{C} 5$ or C6site of the C5-C6 double bond.

\subsection{Addition of aminyl radical to uracil base in 2}

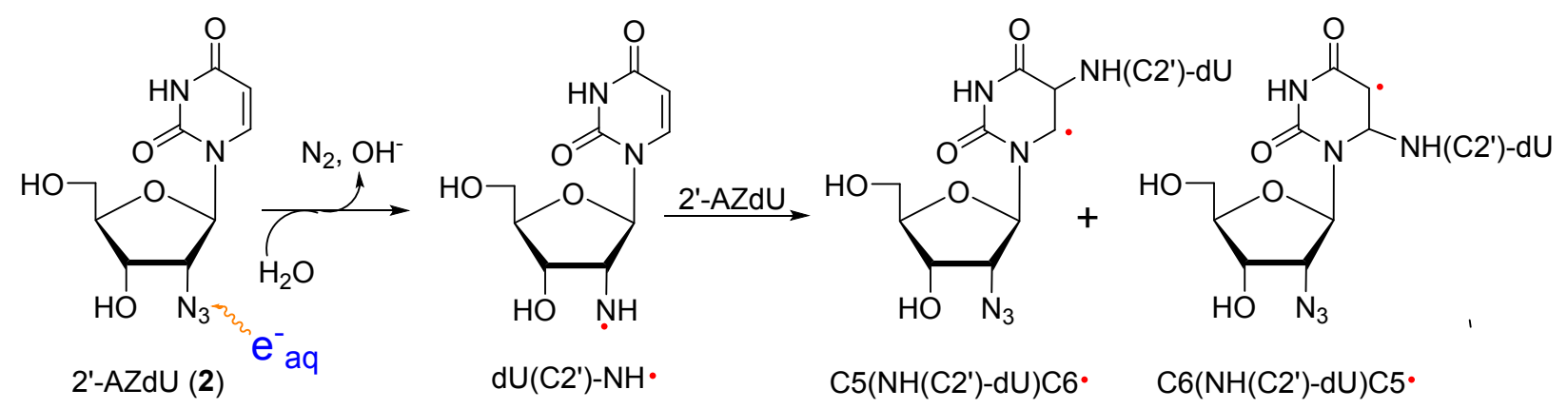

Scheme S3. Electrophilic addition of $\pi-\mathrm{RNH} \bullet\left(\mathrm{dU}\left(\mathrm{C} 2^{\prime}\right)-\mathrm{NH} \bullet\right)$ to the $\mathrm{C} 5=\mathrm{C} 6$ double bond of the uracil base in 2 . 


\section{Theoretical Studies}

$\mathrm{TE}=-400.462615507$ A.U. b3lyp/6-31g** opt Charge $=0 \quad$ Mult $=2$
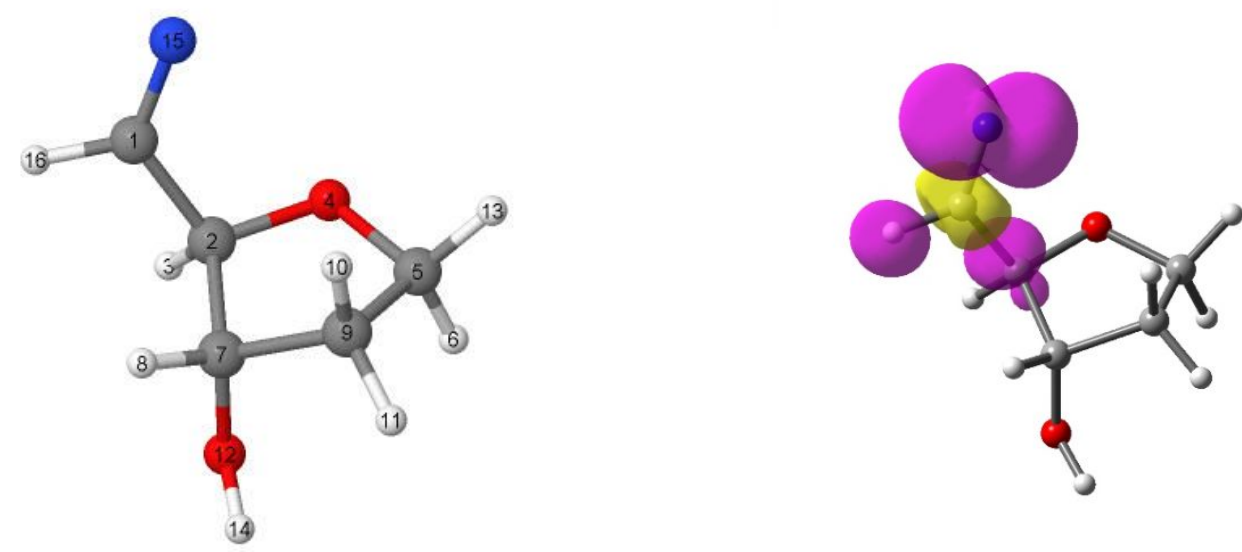

Fully-optimized geometry and spin density distributions of sugar model iminyl radical dR-5'-CH=N•

Isotropic Fermi Contact Couplings

$\begin{array}{rl} & \text { Atom } \\ 1 & \mathrm{C}(13) \\ 2 & \mathrm{C}(13) \\ 3 & \mathrm{H}(1) \\ 4 & \mathrm{O}(17) \\ 5 & \mathrm{C}(13) \\ 6 & \mathrm{H}(1) \\ 7 & \mathrm{C}(13) \\ 8 & \mathrm{H}(1) \\ 9 & \mathrm{C}(13) \\ 10 & \mathrm{H}(1) \\ 11 & \mathrm{H}(1) \\ 12 & \mathrm{O}(17) \\ 13 & \mathrm{H}(1) \\ 14 & \mathrm{H}(1) \\ 15 & \mathrm{~N}(14) \\ 16 & \mathrm{H}(1)\end{array}$

a.u.
-0.05469
0.06870
-0.00139
-0.00138
0.00079
0.00002
-0.00486
0.00005
0.00061
0.00001
0.00000
0.01050
0.00000
0.00055
0.09027
0.04715

MegaHertz

Gauss

$-61.48104$

77.23102

$-21.93796$

27.55795

$-2.21722$

0.29761

0.31667

0.03608

$-1.95071$

0.07923

0.24594

0.01019

0.00576

$-2.27104$

0.00021

0.87587

$10(-4) \mathrm{cm}-1$

0.83406

0.10110

0.22205

0.68924

0.01613

$-6.36458$

0.00059

2. 45462

10.40761

$-20.50787$

25.76150

$-2.07269$

0.27821

0.29603

0.03372

$-1.82354$

0.07407

0.22991

0.00952

0.00538

$-2.12300$

0.00020

0.81877

29.16728

9.72916

210.77071

75.20823

70.30554

Anisotropic Spin Dipole Couplings in Principal Axis System

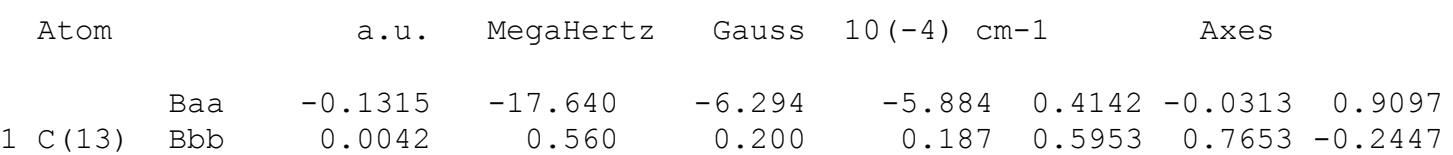




\begin{tabular}{|c|c|c|c|c|c|c|c|c|c|}
\hline & & $\mathrm{BCC}$ & 0.1273 & 17.080 & 6.094 & 5.697 & 0.6885 & -0.6429 & -0.3356 \\
\hline 2 & $C(13)$ & $\begin{array}{l}\mathrm{Baa} \\
\mathrm{Bbb} \\
\mathrm{BCC}\end{array}$ & $\begin{array}{r}-0.0704 \\
-0.0682 \\
0.1386\end{array}$ & $\begin{array}{l}-9.453 \\
-9.146 \\
18.599\end{array}$ & $\begin{array}{r}-3.373 \\
-3.264 \\
6.637\end{array}$ & $\begin{array}{r}-3.153 \\
-3.051 \\
6.204\end{array}$ & $\begin{array}{r}0.3704 \\
-0.1229 \\
0.9207\end{array}$ & $\begin{array}{l}0.1685 \\
0.9836 \\
0.0636\end{array}$ & $\begin{array}{r}0.9135 \\
-0.1316 \\
-0.3850\end{array}$ \\
\hline 3 & $\mathrm{H}(1)$ & $\begin{array}{l}\mathrm{Baa} \\
\mathrm{Bbb} \\
\mathrm{BCC}\end{array}$ & $\begin{array}{r}-0.0093 \\
-0.0037 \\
0.0130\end{array}$ & $\begin{array}{r}-4.968 \\
-1.967 \\
6.935\end{array}$ & $\begin{array}{r}-1.773 \\
-0.702 \\
2.475\end{array}$ & $\begin{array}{r}-1.657 \\
-0.656 \\
2.313\end{array}$ & $\begin{array}{r}-0.2582 \\
0.8463 \\
-0.4659\end{array}$ & $\begin{array}{l}0.7548 \\
0.4777 \\
0.4496\end{array}$ & $\begin{array}{r}-0.6030 \\
0.2355 \\
0.7621\end{array}$ \\
\hline 4 & $O(17)$ & $\begin{array}{l}\text { Baa } \\
\text { Bbb } \\
\text { BcC }\end{array}$ & $\begin{array}{r}-0.0100 \\
-0.0051 \\
0.0151\end{array}$ & $\begin{array}{r}0.722 \\
0.371 \\
-1.093\end{array}$ & $\begin{array}{r}0.258 \\
0.132 \\
-0.390\end{array}$ & $\begin{array}{r}0.241 \\
0.124 \\
-0.365\end{array}$ & $\begin{array}{r}-0.3072 \\
0.4084 \\
0.8595\end{array}$ & $\begin{array}{l}0.9260 \\
0.3364 \\
0.1712\end{array}$ & $\begin{array}{r}-0.2193 \\
0.8485 \\
-0.4816\end{array}$ \\
\hline 5 & $C(13)$ & $\begin{array}{l}\mathrm{Baa} \\
\mathrm{Bbb} \\
\mathrm{BCC}\end{array}$ & $\begin{array}{r}-0.0035 \\
-0.0027 \\
0.0062\end{array}$ & $\begin{array}{r}-0.474 \\
-0.362 \\
0.836\end{array}$ & $\begin{array}{r}-0.169 \\
-0.129 \\
0.298\end{array}$ & $\begin{array}{r}-0.158 \\
-0.121 \\
0.279\end{array}$ & $\begin{array}{r}0.3156 \\
-0.3457 \\
0.8837\end{array}$ & $\begin{array}{r}-0.4440 \\
0.7693 \\
0.4595\end{array}$ & $\begin{array}{r}0.8386 \\
0.5373 \\
-0.0893\end{array}$ \\
\hline 6 & $\mathrm{H}(1)$ & $\begin{array}{l}\text { Baa } \\
\text { Bbb } \\
\text { BcC }\end{array}$ & $\begin{array}{r}-0.0017 \\
-0.0014 \\
0.0032\end{array}$ & $\begin{array}{r}-0.928 \\
-0.764 \\
1.692\end{array}$ & $\begin{array}{r}-0.331 \\
-0.273 \\
0.604\end{array}$ & $\begin{array}{r}-0.309 \\
-0.255 \\
0.564\end{array}$ & $\begin{array}{r}0.2924 \\
-0.3504 \\
0.8898\end{array}$ & $\begin{array}{r}-0.1411 \\
0.9045 \\
0.4025\end{array}$ & $\begin{array}{r}0.9458 \\
0.2432 \\
-0.2151\end{array}$ \\
\hline 7 & $C(13)$ & $\begin{array}{l}\text { Baa } \\
\text { Bbb } \\
\text { BcC }\end{array}$ & $\begin{array}{r}-0.0048 \\
0.0004 \\
0.0044\end{array}$ & $\begin{array}{r}-0.640 \\
0.054 \\
0.586\end{array}$ & $\begin{array}{r}-0.228 \\
0.019 \\
0.209\end{array}$ & $\begin{array}{r}-0.213 \\
0.018 \\
0.195\end{array}$ & $\begin{array}{r}0.4686 \\
-0.3298 \\
0.8195\end{array}$ & $\begin{array}{r}0.7985 \\
-0.2388 \\
-0.5527\end{array}$ & $\begin{array}{l}0.3780 \\
0.9134 \\
0.1514\end{array}$ \\
\hline 8 & $\mathrm{H}(1)$ & $\begin{array}{l}\mathrm{Baa} \\
\mathrm{Bbb} \\
\mathrm{BCC}\end{array}$ & $\begin{array}{r}-0.0032 \\
-0.0028 \\
0.0060\end{array}$ & $\begin{array}{r}-1.714 \\
-1.482 \\
3.196\end{array}$ & $\begin{array}{r}-0.612 \\
-0.529 \\
1.140\end{array}$ & $\begin{array}{r}-0.572 \\
-0.494 \\
1.066\end{array}$ & $\begin{array}{r}-0.4607 \\
0.2284 \\
0.8577\end{array}$ & $\begin{array}{r}-0.3387 \\
0.8480 \\
-0.4077\end{array}$ & $\begin{array}{l}0.8204 \\
0.4783 \\
0.3133\end{array}$ \\
\hline 9 & $C(13)$ & $\begin{array}{l}\text { Baa } \\
\text { Bbb } \\
B C C\end{array}$ & $\begin{array}{r}-0.0031 \\
-0.0031 \\
0.0062\end{array}$ & $\begin{array}{r}-0.420 \\
-0.411 \\
0.831\end{array}$ & $\begin{array}{r}-0.150 \\
-0.147 \\
0.296\end{array}$ & $\begin{array}{r}-0.140 \\
-0.137 \\
0.277\end{array}$ & $\begin{array}{r}-0.2630 \\
-0.1323 \\
0.9557\end{array}$ & $\begin{array}{r}0.7758 \\
-0.6179 \\
0.1279\end{array}$ & $\begin{array}{l}0.5736 \\
0.7750 \\
0.2652\end{array}$ \\
\hline 10 & $\mathrm{H}(1)$ & $\begin{array}{l}\text { Baa } \\
\text { Bbb } \\
B C C\end{array}$ & $\begin{array}{r}-0.0042 \\
-0.0037 \\
0.0078\end{array}$ & $\begin{array}{r}-2.221 \\
-1.952 \\
4.173\end{array}$ & $\begin{array}{r}-0.793 \\
-0.697 \\
1.489\end{array}$ & $\begin{array}{r}-0.741 \\
-0.651 \\
1.392\end{array}$ & $\begin{array}{r}0.0071 \\
-0.5232 \\
0.8522\end{array}$ & $\begin{array}{l}0.9269 \\
0.3232 \\
0.1907\end{array}$ & $\begin{array}{r}-0.3752 \\
0.7885 \\
0.4873\end{array}$ \\
\hline 11 & $\mathrm{H}(1)$ & $\begin{array}{l}\mathrm{Baa} \\
\mathrm{Bbb} \\
\mathrm{BCC}\end{array}$ & $\begin{array}{r}-0.0014 \\
-0.0013 \\
0.0027\end{array}$ & $\begin{array}{r}-0.767 \\
-0.689 \\
1.456\end{array}$ & $\begin{array}{r}-0.274 \\
-0.246 \\
0.520\end{array}$ & $\begin{array}{r}-0.256 \\
-0.230 \\
0.486\end{array}$ & $\begin{array}{r}0.0202 \\
-0.3256 \\
0.9453\end{array}$ & $\begin{array}{l}0.8674 \\
0.4759 \\
0.1454\end{array}$ & $\begin{array}{r}-0.4972 \\
0.8170 \\
0.2920\end{array}$ \\
\hline 12 & $O(17)$ & $\begin{array}{l}\mathrm{Baa} \\
\mathrm{Bbb} \\
\mathrm{BCC}\end{array}$ & $\begin{array}{r}-0.0051 \\
-0.0047 \\
0.0097\end{array}$ & $\begin{array}{r}0.367 \\
0.337 \\
-0.704\end{array}$ & $\begin{array}{r}0.131 \\
0.120 \\
-0.251\end{array}$ & $\begin{array}{r}0.122 \\
0.113 \\
-0.235\end{array}$ & $\begin{array}{r}-0.1860 \\
0.5030 \\
0.8440\end{array}$ & $\begin{array}{r}-0.3546 \\
0.7668 \\
-0.5351\end{array}$ & $\begin{array}{r}0.9163 \\
0.3989 \\
-0.0358\end{array}$ \\
\hline 13 & $\mathrm{H}(1)$ & $\begin{array}{l}\text { Baa } \\
\text { Bbb } \\
\text { BcC }\end{array}$ & $\begin{array}{r}-0.0027 \\
-0.0023 \\
0.0050\end{array}$ & $\begin{array}{r}-1.427 \\
-1.241 \\
2.668\end{array}$ & $\begin{array}{r}-0.509 \\
-0.443 \\
0.952\end{array}$ & $\begin{array}{r}-0.476 \\
-0.414 \\
0.890\end{array}$ & $\begin{array}{r}0.3201 \\
-0.5697 \\
0.7570\end{array}$ & $\begin{array}{r}-0.3103 \\
0.6919 \\
0.6519\end{array}$ & $\begin{array}{r}0.8951 \\
0.4436 \\
-0.0447\end{array}$ \\
\hline 14 & $\mathrm{H}(1)$ & $\begin{array}{l}\text { Baa } \\
\text { Bbb } \\
B c C\end{array}$ & $\begin{array}{r}-0.0012 \\
-0.0010 \\
0.0022\end{array}$ & $\begin{array}{r}-0.624 \\
-0.533 \\
1.157\end{array}$ & $\begin{array}{r}-0.223 \\
-0.190 \\
0.413\end{array}$ & $\begin{array}{r}-0.208 \\
-0.178 \\
0.386\end{array}$ & $\begin{array}{l}0.2536 \\
0.0452 \\
0.9663\end{array}$ & $\begin{array}{r}0.8259 \\
0.5099 \\
-0.2406\end{array}$ & $\begin{array}{r}-0.5036 \\
0.8590 \\
0.0920\end{array}$ \\
\hline 15 & $N(14)$ & $\begin{array}{l}\text { Baa } \\
\text { Bbb } \\
\text { BcC }\end{array}$ & $\begin{array}{r}-1.0788 \\
-0.8214 \\
1.9002\end{array}$ & $\begin{array}{r}-41.609 \\
-31.679 \\
73.288\end{array}$ & $\begin{array}{r}-14.847 \\
-11.304 \\
26.151\end{array}$ & $\begin{array}{r}-13.879 \\
-10.567 \\
24.446\end{array}$ & $\begin{array}{l}0.6737 \\
0.4288 \\
0.6019\end{array}$ & $\begin{array}{r}-0.6589 \\
-0.0201 \\
0.7519\end{array}$ & $\begin{array}{r}-0.3345 \\
0.9032 \\
-0.2690\end{array}$ \\
\hline 16 & $\mathrm{H}(1)$ & $\begin{array}{l}\text { Baa } \\
\text { Bbb } \\
\text { BCC }\end{array}$ & $\begin{array}{r}-0.0119 \\
-0.0066 \\
0.0185\end{array}$ & $\begin{array}{r}-6.339 \\
-3.546 \\
9.885\end{array}$ & $\begin{array}{r}-2.262 \\
-1.265 \\
3.527\end{array}$ & $\begin{array}{r}-2.114 \\
-1.183 \\
3.297\end{array}$ & $\begin{array}{r}0.4350 \\
0.7575 \\
-0.4867\end{array}$ & $\begin{array}{r}-0.0129 \\
0.5458 \\
0.8378\end{array}$ & $\begin{array}{r}0.9003 \\
-0.3582 \\
0.2472\end{array}$ \\
\hline
\end{tabular}


$\mathrm{TE}=-509.921785696 \mathrm{~A} . \mathrm{U} . \quad$ b3lyp/6-31g** opt Charge $=0$ Mult $=2$

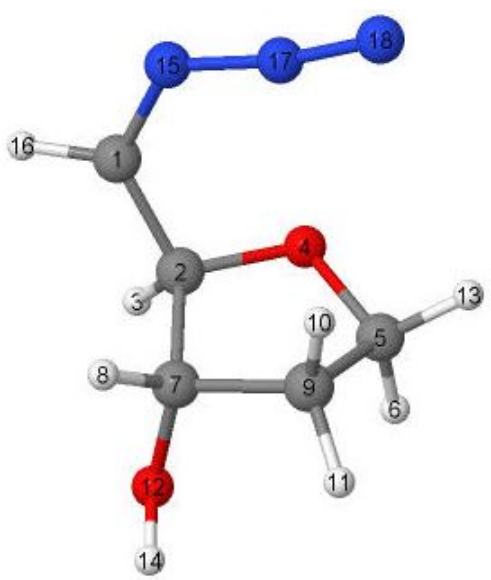

Fully-optimized geometry of sugar model 5 '- $\alpha$-azidomethyl radical dR-5'-CH・- $\mathrm{N}_{3}$. Base part is not considered in the calculation.

Isotropic Fermi Contact Couplings

\begin{tabular}{rlrrrr} 
& Atom & a.u. & MegaHertz & Gauss & \multicolumn{1}{c}{ 10 $(-4) \mathrm{cm}-1$} \\
1 & $\mathrm{C}(13)$ & 0.08095 & 91.00178 & 32.47170 & \multicolumn{1}{c}{30.35493} \\
2 & $\mathrm{C}(13)$ & -0.02033 & -22.85122 & -8.15388 & -7.62235 \\
3 & $\mathrm{H}(1)$ & 0.00695 & 31.06832 & 11.08595 & 10.36328 \\
4 & $\mathrm{O}(17)$ & 0.00947 & -5.74056 & -2.04837 & -1.91484 \\
5 & $\mathrm{C}(13)$ & -0.00076 & -0.85051 & -0.30348 & -0.28370 \\
6 & $\mathrm{H}(1)$ & -0.00003 & -0.12405 & -0.04426 & -0.04138 \\
7 & $\mathrm{C}(13)$ & 0.04469 & 50.23745 & 17.92597 & 16.75741 \\
8 & $\mathrm{H}(1)$ & 0.00002 & 0.07230 & 0.02580 & 0.02412 \\
9 & $\mathrm{C}(13)$ & 0.00048 & 0.53515 & 0.19095 & 0.17851 \\
10 & $\mathrm{H}(1)$ & -0.00005 & -0.22872 & -0.08161 & -0.07629 \\
11 & $\mathrm{H}(1)$ & 0.00061 & 2.71991 & 0.97053 & 0.90726 \\
12 & $\mathrm{O}(17)$ & 0.00321 & -1.94390 & -0.69363 & -0.64842 \\
13 & $\mathrm{H}(1)$ & 0.00010 & 0.42829 & 0.15282 & 0.14286 \\
14 & $\mathrm{H}(1)$ & 0.00048 & 2.13922 & 0.76333 & 0.71357 \\
15 & $\mathrm{~N}(14)$ & -0.02267 & -7.32580 & -2.61403 & -2.44362 \\
16 & $\mathrm{H}(1)$ & -0.01175 & -52.54340 & -18.74879 & -17.52659 \\
17 & $\mathrm{~N}(14)$ & 0.00392 & 1.26628 & 0.45184 & 0.42239 \\
18 & $\mathrm{~N}(14)$ & 0.03557 & 11.49155 & 4.10047 & 3.83317
\end{tabular}

Anisotropic Spin Dipole Couplings in Principal Axis System

\begin{tabular}{|c|c|c|c|c|c|c|c|c|c|}
\hline & Atom & & a.u. & MegaHertz & Gauss & $10(-4) \mathrm{Cn}$ & $n-1$ & Axes & \\
\hline 1 & $C(13)$ & $\begin{array}{l}\text { Baa } \\
\text { Bbb } \\
\text { BCC }\end{array}$ & $\begin{array}{r}-0.4144 \\
-0.3912 \\
0.8056\end{array}$ & $\begin{array}{l}-55.611 \\
-52.495 \\
108.105\end{array}$ & $\begin{array}{r}-19.843 \\
-18.731 \\
38.575\end{array}$ & $\begin{array}{r}-18.550 \\
-17.510 \\
36.060\end{array}$ & $\begin{array}{r}0.9390 \\
-0.1593 \\
0.3046\end{array}$ & $\begin{array}{r}0.1779 \\
0.9835 \\
-0.0341\end{array}$ & $\begin{array}{r}-0.2942 \\
0.0862 \\
0.9519\end{array}$ \\
\hline 2 & $C(13)$ & $\begin{array}{l}\text { Baa } \\
\text { Bbb } \\
\text { BcC }\end{array}$ & $\begin{array}{r}-0.0081 \\
-0.0039 \\
0.0120\end{array}$ & $\begin{array}{r}-1.091 \\
-0.523 \\
1.614\end{array}$ & $\begin{array}{r}-0.389 \\
-0.187 \\
0.576\end{array}$ & $\begin{array}{r}-0.364 \\
-0.175 \\
0.538\end{array}$ & $\begin{array}{r}0.1482 \\
0.8504 \\
-0.5048\end{array}$ & $\begin{array}{l}0.1428 \\
0.4867 \\
0.8618\end{array}$ & $\begin{array}{r}0.9786 \\
-0.1998 \\
-0.0493\end{array}$ \\
\hline
\end{tabular}




\begin{tabular}{|c|c|c|c|c|c|c|c|c|c|}
\hline 3 & $\mathrm{H}(1)$ & $\begin{array}{l}\mathrm{Baa} \\
\mathrm{Bbb} \\
\mathrm{BCC}\end{array}$ & $\begin{array}{r}-0.0087 \\
-0.0057 \\
0.0144\end{array}$ & $\begin{array}{r}-4.618 \\
-3.041 \\
7.658\end{array}$ & $\begin{array}{r}-1.648 \\
-1.085 \\
2.733\end{array}$ & $\begin{array}{r}-1.540 \\
-1.014 \\
2.555\end{array}$ & $\begin{array}{l}0.1185 \\
0.4878 \\
0.8649\end{array}$ & $\begin{array}{r}0.9907 \\
0.0009 \\
-0.1362\end{array}$ & $\begin{array}{r}-0.0672 \\
0.8730 \\
-0.4831\end{array}$ \\
\hline 4 & $O(17)$ & $\begin{array}{l}\mathrm{Baa} \\
\mathrm{Bbb} \\
\mathrm{BCC}\end{array}$ & $\begin{array}{r}-0.0276 \\
-0.0139 \\
0.0415\end{array}$ & $\begin{array}{r}1.996 \\
1.007 \\
-3.003\end{array}$ & $\begin{array}{r}0.712 \\
0.359 \\
-1.072\end{array}$ & $\begin{array}{r}0.666 \\
0.336 \\
-1.002\end{array}$ & $\begin{array}{l}0.7542 \\
0.6566 \\
0.0017\end{array}$ & $\begin{array}{r}0.3101 \\
-0.3585 \\
0.8805\end{array}$ & $\begin{array}{r}-0.5788 \\
0.6635 \\
0.4741\end{array}$ \\
\hline 5 & $C(13)$ & $\begin{array}{l}\mathrm{Baa} \\
\mathrm{Bbb} \\
\mathrm{BCC}\end{array}$ & $\begin{array}{r}-0.0021 \\
-0.0017 \\
0.0039\end{array}$ & $\begin{array}{r}-0.284 \\
-0.234 \\
0.518\end{array}$ & $\begin{array}{r}-0.101 \\
-0.084 \\
0.185\end{array}$ & $\begin{array}{r}-0.095 \\
-0.078 \\
0.173\end{array}$ & $\begin{array}{r}0.2847 \\
0.7693 \\
-0.5719\end{array}$ & $\begin{array}{l}0.1724 \\
0.5458 \\
0.8200\end{array}$ & $\begin{array}{r}0.9430 \\
-0.3320 \\
0.0228\end{array}$ \\
\hline 6 & $\mathrm{H}(1)$ & $\begin{array}{l}\mathrm{Baa} \\
\mathrm{Bbb} \\
\mathrm{BCC}\end{array}$ & $\begin{array}{r}-0.0017 \\
-0.0012 \\
0.0029\end{array}$ & $\begin{array}{r}-0.889 \\
-0.643 \\
1.532\end{array}$ & $\begin{array}{r}-0.317 \\
-0.229 \\
0.546\end{array}$ & $\begin{array}{r}-0.296 \\
-0.214 \\
0.511\end{array}$ & $\begin{array}{r}0.2638 \\
0.7049 \\
-0.6584\end{array}$ & $\begin{array}{r}-0.1894 \\
0.7072 \\
0.6812\end{array}$ & $\begin{array}{r}0.9458 \\
-0.0550 \\
0.3201\end{array}$ \\
\hline 7 & C (13) & $\begin{array}{l}\mathrm{Baa} \\
\mathrm{Bbb} \\
\mathrm{BCC}\end{array}$ & $\begin{array}{r}-0.0318 \\
-0.0286 \\
0.0604\end{array}$ & $\begin{array}{r}-4.265 \\
-3.842 \\
8.107\end{array}$ & $\begin{array}{r}-1.522 \\
-1.371 \\
2.893\end{array}$ & $\begin{array}{r}-1.423 \\
-1.282 \\
2.704\end{array}$ & $\begin{array}{r}0.7573 \\
-0.2207 \\
0.6147\end{array}$ & $\begin{array}{r}0.6188 \\
0.5436 \\
-0.5671\end{array}$ & $\begin{array}{r}-0.2090 \\
0.8098 \\
0.5482\end{array}$ \\
\hline 8 & $\mathrm{H}(1)$ & $\begin{array}{l}\mathrm{Baa} \\
\mathrm{Bbb} \\
\mathrm{BCC}\end{array}$ & $\begin{array}{r}-0.0084 \\
-0.0024 \\
0.0107\end{array}$ & $\begin{array}{r}-4.471 \\
-1.262 \\
5.733\end{array}$ & $\begin{array}{r}-1.595 \\
-0.450 \\
2.046\end{array}$ & $\begin{array}{r}-1.491 \\
-0.421 \\
1.912\end{array}$ & $\begin{array}{l}0.4623 \\
0.6534 \\
0.5995\end{array}$ & $\begin{array}{r}0.8398 \\
-0.5397 \\
-0.0594\end{array}$ & $\begin{array}{r}-0.2848 \\
-0.5309 \\
0.7982\end{array}$ \\
\hline 9 & $C(13)$ & $\begin{array}{l}\mathrm{Baa} \\
\mathrm{Bbb} \\
\mathrm{BCC}\end{array}$ & $\begin{array}{r}-0.0068 \\
-0.0014 \\
0.0082\end{array}$ & $\begin{array}{r}-0.918 \\
-0.182 \\
1.099\end{array}$ & $\begin{array}{r}-0.327 \\
-0.065 \\
0.392\end{array}$ & $\begin{array}{r}-0.306 \\
-0.061 \\
0.367\end{array}$ & $\begin{array}{r}-0.1739 \\
0.9759 \\
0.1315\end{array}$ & $\begin{array}{r}0.1890 \\
-0.0979 \\
0.9771\end{array}$ & $\begin{array}{r}0.9665 \\
0.1948 \\
-0.1674\end{array}$ \\
\hline 10 & $\mathrm{H}(1)$ & $\begin{array}{l}\mathrm{Baa} \\
\mathrm{Bbb} \\
\mathrm{BCC}\end{array}$ & $\begin{array}{r}-0.0042 \\
0.0001 \\
0.0041\end{array}$ & $\begin{array}{r}-2.260 \\
0.073 \\
2.187\end{array}$ & $\begin{array}{r}-0.806 \\
0.026 \\
0.780\end{array}$ & $\begin{array}{r}-0.754 \\
0.024 \\
0.730\end{array}$ & $\begin{array}{r}-0.1801 \\
0.7777 \\
-0.6022\end{array}$ & $\begin{array}{l}0.4398 \\
0.6113 \\
0.6579\end{array}$ & $\begin{array}{r}0.8798 \\
-0.1464 \\
-0.4522\end{array}$ \\
\hline 11 & $\mathrm{H}(1)$ & $\begin{array}{l}\mathrm{Baa} \\
\mathrm{Bbb} \\
\mathrm{BCC}\end{array}$ & $\begin{array}{r}-0.0023 \\
-0.0008 \\
0.0031\end{array}$ & $\begin{array}{r}-1.242 \\
-0.420 \\
1.662\end{array}$ & $\begin{array}{r}-0.443 \\
-0.150 \\
0.593\end{array}$ & $\begin{array}{r}-0.414 \\
-0.140 \\
0.554\end{array}$ & $\begin{array}{r}-0.1882 \\
0.6938 \\
0.6951\end{array}$ & $\begin{array}{r}0.2583 \\
0.7178 \\
-0.6466\end{array}$ & $\begin{array}{r}0.9476 \\
-0.0579 \\
0.3143\end{array}$ \\
\hline 12 & $O(17)$ & $\begin{array}{l}\mathrm{Baa} \\
\mathrm{Bbb} \\
\mathrm{BcC}\end{array}$ & $\begin{array}{r}-0.0080 \\
-0.0057 \\
0.0137\end{array}$ & $\begin{array}{r}0.581 \\
0.411 \\
-0.991\end{array}$ & $\begin{array}{r}0.207 \\
0.146 \\
-0.354\end{array}$ & $\begin{array}{r}0.194 \\
0.137 \\
-0.331\end{array}$ & $\begin{array}{l}0.3784 \\
0.3890 \\
0.8399\end{array}$ & $\begin{array}{r}0.7230 \\
0.4425 \\
-0.5306\end{array}$ & $\begin{array}{r}-0.5781 \\
0.8080 \\
-0.1138\end{array}$ \\
\hline 13 & $\mathrm{H}(1)$ & $\begin{array}{l}\mathrm{Baa} \\
\mathrm{Bbb} \\
\mathrm{BCC}\end{array}$ & $\begin{array}{r}-0.0026 \\
-0.0008 \\
0.0035\end{array}$ & $\begin{array}{r}-1.411 \\
-0.448 \\
1.859\end{array}$ & $\begin{array}{r}-0.503 \\
-0.160 \\
0.663\end{array}$ & $\begin{array}{r}-0.470 \\
-0.149 \\
0.620\end{array}$ & $\begin{array}{r}0.2386 \\
0.7532 \\
-0.6130\end{array}$ & $\begin{array}{r}-0.1272 \\
0.6500 \\
0.7492\end{array}$ & $\begin{array}{r}0.9627 \\
-0.1008 \\
0.2509\end{array}$ \\
\hline 14 & $\mathrm{H}(1)$ & $\begin{array}{l}\mathrm{Baa} \\
\mathrm{Bbb} \\
\mathrm{BCC}\end{array}$ & $\begin{array}{r}-0.0019 \\
-0.0014 \\
0.0033\end{array}$ & $\begin{array}{r}-0.998 \\
-0.755 \\
1.753\end{array}$ & $\begin{array}{r}-0.356 \\
-0.269 \\
0.626\end{array}$ & $\begin{array}{r}-0.333 \\
-0.252 \\
0.585\end{array}$ & $\begin{array}{r}0.1347 \\
-0.2561 \\
0.9572\end{array}$ & $\begin{array}{r}0.9687 \\
-0.1693 \\
-0.1816\end{array}$ & $\begin{array}{l}0.2085 \\
0.9517 \\
0.2253\end{array}$ \\
\hline 15 & $N(14)$ & $\begin{array}{l}\mathrm{Baa} \\
\mathrm{Bbb} \\
\mathrm{BCC}\end{array}$ & $\begin{array}{r}-0.0868 \\
0.0015 \\
0.0852\end{array}$ & $\begin{array}{r}-3.346 \\
0.060 \\
3.287\end{array}$ & $\begin{array}{r}-1.194 \\
0.021 \\
1.173\end{array}$ & $\begin{array}{r}-1.116 \\
0.020 \\
1.096\end{array}$ & $\begin{array}{l}0.3307 \\
0.7492 \\
0.5739\end{array}$ & $\begin{array}{r}0.1409 \\
-0.6405 \\
0.7550\end{array}$ & $\begin{array}{r}0.9332 \\
-0.1689 \\
-0.3173\end{array}$ \\
\hline 16 & $\mathrm{H}(1)$ & $\begin{array}{l}\mathrm{Baa} \\
\mathrm{Bbb} \\
\mathrm{BCC}\end{array}$ & $\begin{array}{r}-0.0535 \\
-0.0011 \\
0.0546\end{array}$ & $\begin{array}{r}-28.569 \\
-0.574 \\
29.143\end{array}$ & $\begin{array}{r}-10.194 \\
-0.205 \\
10.399\end{array}$ & $\begin{array}{r}-9.530 \\
-0.192 \\
9.721\end{array}$ & $\begin{array}{l}0.9466 \\
0.3177 \\
0.0558\end{array}$ & $\begin{array}{r}-0.0188 \\
-0.1181 \\
0.9928\end{array}$ & $\begin{array}{r}-0.3220 \\
0.9408 \\
0.1058\end{array}$ \\
\hline 17 & $N(14)$ & $\begin{array}{l}\mathrm{Baa} \\
\mathrm{Bbb} \\
\mathrm{BCC}\end{array}$ & $\begin{array}{r}-0.1478 \\
-0.0349 \\
0.1827\end{array}$ & $\begin{array}{r}-5.700 \\
-1.345 \\
7.045\end{array}$ & $\begin{array}{r}-2.034 \\
-0.480 \\
2.514\end{array}$ & $\begin{array}{r}-1.901 \\
-0.449 \\
2.350\end{array}$ & $\begin{array}{l}0.8238 \\
0.4852 \\
0.2932\end{array}$ & $\begin{array}{r}-0.4771 \\
0.8727 \\
-0.1037\end{array}$ & $\begin{array}{r}-0.3062 \\
-0.0545 \\
0.9504\end{array}$ \\
\hline 18 & $N(14)$ & $\begin{array}{l}\mathrm{Baa} \\
\mathrm{Bbb} \\
\mathrm{BcC}\end{array}$ & $\begin{array}{r}-0.4264 \\
-0.3447 \\
0.7712\end{array}$ & $\begin{array}{r}-16.447 \\
-13.295 \\
29.742\end{array}$ & $\begin{array}{l}-5.869 \\
-4.744 \\
10.613\end{array}$ & $\begin{array}{r}-5.486 \\
-4.435 \\
9.921\end{array}$ & $\begin{array}{l}0.3096 \\
0.9031 \\
0.2976\end{array}$ & $\begin{array}{r}0.9478 \\
-0.3181 \\
-0.0206\end{array}$ & $\begin{array}{r}-0.0761 \\
-0.2885 \\
0.9545\end{array}$ \\
\hline
\end{tabular}




\section{References}

1. Földesi, A.; Kundu, M.; Dinya, Z.; Chattopadhyaya, J., Synthesis of [2'-2H1]Ribonucleosides. Helv. Chim. Acta 2004, 87, 742-757.

2. Lawhorn, B. G.; Mehl, R. A.; Begley, T. P., Biosynthesis of the thiamin pyrimidine: the reconstitution of a remarkable rearrangement reaction. Org. Biomol. Chem. 2004, 2, 25382546.

3. Baker, S. J.; Young, D. W., Synthesis of [1-2H]- and [3-2H]-guanosine. J. Labelled Cpd. Radiopharm. 2000, 43, 1023-1032.

4. Xie, M.; Berges, D. A.; Robins, M. J., Efficient "Dehomologation" of Di-OIsopropylidenehexofuranose Derivatives To Give O-Isopropylidenepentofuranoses by Sequential Treatment with Periodic Acid in Ethyl Acetate and Sodium Borohydride. J. Org. Chem. 1996, 61, 5178-5179.

5. Zipse, H.; Artin, E.; Wnuk, S.; Lohman, G. J. S.; Martino, D.; Griffin, R. G.; Kacprzak, S.; Kaupp, M.; Hoffman, B.; Bennati, M.; Stubbe, J.; Lees, N., Structure of the Nucleotide Radical Formed during Reaction of CDP/TTP with the E441Q-a2b2 of E. coli Ribonucleotide Reductase. J. Am. Chem. Soc. 2009, 131, 200-211.

6. Vorbrüggen, H.; Bennua, B., A new simplified nucleoside synthesis Chemische Berichte 1981, 114, 1279-1286.

7. Hampton, A.; Nichol, A. W., Nucleotides. V. Purine Ribonucleoside 2',3'-Cyclic Carbonates. Preparation and Use for the Synthesis of 5'-Monosubstituted Nucleosides. Biochemistry 1966, 5, 2076-2082.

8. Salowe, S.; Bollinger, J. M., Jr.; Ator, M.; Stubbe, J.; McCracken, J.; Peisach, J.; Samano, M. C.; Robins, M. J., Alternative model for mechanism-based inhibition of Escherichia coli ribonucleotide reductase by 2'-azido-2'-deoxyuridine 5'-diphosphate. Biochemistry 1993, 32, 12749-12760.

9. Pang, H.; Schram, K. H.; Smith, D. L.; Gupta, S. P.; Townsend, L. B.; McCloskey, J. A., Mass spectrometry of nucleic acid constituents. Trimethylsilyl derivatives of nucleosides. $J$. Org. Chem. 1982, 47, 3923-3932.

10. Adhikary, A.; Becker, D.; Sevilla, M. D., Electron Spin Resonance of Radicals in Irradiated DNA. In Applications of EPR in Radiation Research, Lund, A.; Shiotani, M., Eds. Springer International Publishing: 2014; pp 299-352.

11. Adhikary, A.; Kumar, A.; Becker, D.; Sevilla, M. D. The guanine Cation Radical: Investigation of Deprotonation States by ESR and DFT. J. Phys Chem. B 2006, 110, 24170 - 24180.

12. Adhikary, A.; Khanduri, D.; Sevilla, M. D. Direct Observation of The Hole Protonation State and Hole Localization Site in DNA-Oligomers. J. Am. Chem. Soc. 2009, 131, $8614-8619$.

13. Adhikary, A.; Kumar, A.; Munafo, S. A.; Khanduri, D.; Sevilla, M. D. Prototropic Equilibria in DNA Containing One-electron Oxidized GC: Intra-duplex vs. Duplex to Solvent Deprotonation. Phys. Chem. Chem. Phys. 2010, 12, $5353-5368$.

14. Khanduri, D.; Adhikary, A.; Sevilla, M. D. Highly Oxidizing Excited States of One-electron Oxidized Guanine in DNA: Wavelength and pH Dependence. J. Am. Chem. Soc. 2011, 133, 4527 - 4537.

15. Adhikary, A.; Kumar, A.; Rayala, R.; Hindi, R. M.; Adhikary, A.; Wnuk, S. F.; Sevilla, M. D. OneElectron Oxidation of Gemcitabine and Analogs: Mechanism of Formation of $\mathrm{C}^{\prime}$ and $\mathrm{C}^{\prime}$ 'Sugar Radicals. J. Am. Chem. Soc. 2014, 136, 15646 - 15653.

16. Adhikary, A.; Kumar, A.; Palmer, B. J.; Todd, A. D.; Heizer, A. N.; Sevilla, M. D. Reactions of 5Methylcytosine Cation Radicals in DNA and Model Systems: Thermal Deprotonation From the 5Methyl Group vs. Excited State Deprotonation From Sugar. Int. J. Radiat. Biol. 2014, 90, 433 - 445. 
17. Adhikary, A.; Kumar, A.; Bishop, C. T.; Wiegand, T. J.; Hindi, R. M.; Adhikary, A.; Sevilla, M. D. $\pi$-Radical to $\sigma$-Radical Tautomerization in One-Electron-Oxidized 1-Methylcytosine and Its Analogs. J. Phys. Chem. B 2015, 119, $11496-11505$.

18. Adhikary, A.; Kumar, A.; Khanduri, D.; Sevilla, M. D. The Effect of Base Stacking on The Acid-base Properties of The Adenine Cation Radical $\left[\mathrm{A}^{\bullet^{+}}\right.$] in Solution: ESR and DFT Studies. J. Am. Chem. Soc. 2008, 130, 10282 - 10292.

19. Adhikary, A.; Khanduri, D.; Kumar, A.; Sevilla, M. D. Photo-excitation of Adenine cation radical $\left[\mathrm{A}^{\bullet}\right]$ in The Near UV-vis Region Produces Sugar Radicals in Adenosine and in Its Nucleotides. $J$. Phys. Chem. B 2008, 112, $15844-15855$.

20. Banyasz, A.; Tiia-Maaria, K.; Muñoz-Losa, A.; Rishi, S.; Adhikary, A.; Sevilla, M. D.; MartinezFernandez, L.; Improta, R.; Markovitsi, D. UV-induced adenine radicals induced in DNA A Tracts: Spectral and Dynamical Characterization. J. Phys. Chem. Lett. 2016, 7, 3949 - 3953.

21. Adhikary, A.; Khanduri, D.; Pottiboyina, V.; Rice, C. T.; Sevilla, M. D. Formation of Aminyl Radicals on Electron Attachment to AZT: Abstraction From the Sugar Phosphate Backbone vs. OneElectron Oxidation of Guanine. J. Phys. Chem. B 2010, 114, 9289 - 9299.

22. Petrovici, A.; Adhikary, A.; Kumar, A.; Sevilla, M. D. Presolvated Electron Reaction with Methylacetoacetate: Electron Localization, Proton-Deuteron Exchange, and H-atom Abstraction. Molecules (Special Issue "Free Radicals and Radical Ions" (Walton, J. C. and Williams, F. (Eds.))), 2014, 19, 13486 - 13497.

23. Adhikary, A.; Kumar, A.; Khanduri, D.; Sevilla, M. D. The Effect of Base Stacking on The Acid-base Properties of The Adenine Cation Radical $\left[\mathrm{A}^{\left.\bullet^{+}\right]}\right.$in Solution: ESR and DFT Studies. J. Am. Chem. Soc. 2008, 130, 10282 - 10292.

24. Adhikary, A.; Becker, D.; Palmer, B. J.; Heizer, A. N., and Sevilla, M. D. Direct Formation of The C5'-Radical in The Sugar-Phosphate Backbone of DNA by High Energy Radiation. J. Phys. Chem. B 2012, 116, $5900-5906$.

25. Frisch, M. J.; Trucks, G. W.; Schlegel, H. B.; Scuseria, G. E.; Robb, M. A.; Cheeseman, J. R.; Scalmani, G.; Barone, V.; Mennucci, B.; Petersson, G. A. et al. Gaussian 09; Gaussian, Inc.: Wallingford, CT, 2009.

26. Raiti, M. J.; Sevilla, M. D. Density Functional Theory Investigation of The Electronic Structure and Spin Density Distribution in Peroxyl Radicals. J. Phys. Chem. A 1999, 103, $1619-1626$.

27. http://jmol.sourceforge.net 